\title{
On the nature of halogen bonded complexes between carbonyl bases and chlorotrifluoromethane
}

\author{
Wiktor Zierkiewicz ${ }^{1}$ (1) $\cdot$ Dariusz C. Bieńko $^{1} \cdot$ Danuta Michalska $^{1}$ • \\ Thérèse Zeegers-Huyskens ${ }^{2}$
}

Received: 17 July 2015 / Accepted: 21 July 2015 / Published online: 9 August 2015

(C) The Author(s) 2015. This article is published with open access at Springerlink.com

\begin{abstract}
The structures and intermolecular interactions in the halogen bonded complexes of six carbonyl bases with chlorotrifluoromethane have been studied by ab initio MP2 and $\operatorname{CCSD}(T)$ as well as density functional methods: B3LYP, B3LYP-D3 and wB97XD. The CCSD(T)/aug-ccpVTZ calculated interaction energies of these complexes range between -1.22 and $-2.62 \mathrm{kcal} \mathrm{mol}^{-1}$. The interaction energies are related to the ionization potential and proton affinity of the carbonyl bases. The intermolecular interaction results in a contraction of the $\mathrm{C}-\mathrm{Cl}$ bond and an elongation of the $\mathrm{C}-\mathrm{F}$ bonds accompanied by a relevant frequency shift of the corresponding stretching vibrations. The origin of the variation of the $\mathrm{C}-\mathrm{Cl}$ and $\mathrm{C}-\mathrm{F}$ bond lengths is discussed on the basis of an NBO analysis. It is suggested that the formation of these complexes can be considered as a two-step mechanism, involving the intermolecular charge transfer from the lone-pair orbitals on the oxygen atom to the antibonding $\sigma^{*}(\mathrm{C}-\mathrm{Cl})$ orbital followed by a decrease of the intramolecular charge transfer from the lone-pair orbitals on the fluorine atoms to the antibonding $\sigma^{*}(\mathrm{C}-\mathrm{Cl})$ orbital. A symmetry-adapted perturbation theory (SAPT) decomposition of the interaction energies has been performed.
\end{abstract}

Wiktor Zierkiewicz

Wiktor.Zierkiewicz@pwr.edu.pl

Thérèse Zeegers-Huyskens

Therese.Zeegers@chem.kuleuven.be

1 Faculty of Chemistry, Wrocław University of Technology, Wybrzeże Wyspiańskiego 27, 50-370 Wrocław, Poland

2 Department of Chemistry, University of Leuven, 200F Celestijnenlaan, 3001 Heverlee, Belgium
Keywords Halogen bond - Carbonyl bases - DFT · MP2 . $\operatorname{CCSD}(\mathrm{T})$

\section{Introduction}

Classical textbooks on molecular interactions mainly devoted to hydrogen bonds [1] and charge transfer complexes [2] have appeared in the years 1960-1970. It is only in the late 1990s that charge transfer complexes involving an $\mathrm{X}$ halogen atom in the ZX $\cdots \mathrm{Y}$ system have been recalled halogen bonds. They involve an interaction of an electronrich center $\mathrm{Y}$ with an electronegative halogen substituent in a ZX molecule. These bonds have been featured in an increasing numbers of areas. Their importance in the field of molecular recognition [3, 4] and crystal engineering [5] as well as in biological systems [6] also has been recognized. This wide range of applications has placed the halogen bonded interactions in a center of great attention, and many theoretical works have been focused on them [7-20].

In this work, we present the results of a theoretical investigation of the interaction between chlorotrifluoromethane $\left(\mathrm{CClF}_{3}\right)$ and substituted carbonyl derivatives. Let us notice that the complexes between trifluoromethyl halides $\left(\mathrm{CF}_{3} \mathrm{X}\right)$ and guest molecules have been the subject of several theoretical investigations, as for example the interaction between $\mathrm{CClF}_{3}$ and $\mathrm{NH}_{3}$ [21, 22], $\mathrm{H}_{2} \mathrm{O}$ [23, 24], $\mathrm{H}_{2} \mathrm{~S}$ [25], organic bases of different nature [26-29] or halide anions [30]. The influence of angular distortions on the energies of halogen bonds and hydrogen bonds has been recently discussed [31]. Very few experimental data on these interactions are available. The vibrational properties of trifluoromethyl halides complexed with dimethyl ether have been investigated by IR and Raman spectroscopies in liquid argon and in liquid krypton [32]. The halogen bond 
formed between $\mathrm{CClF}_{3}$ and dimethyl ether has been studied by rotational spectroscopy [33].

Although halogen atoms carry partial negative charges, there is a positive electrostatic potential at the head of the lone pair in the opposite direction of this lone pair. This region is called a $\sigma$-hole which accounts for the ability of halogens to accept an interaction with electronic rich atoms [34-36]. A $\sigma$-hole has been predicted in the $\mathrm{Cl}$ atom of $\mathrm{CClF}_{3}[34]$.

It has been shown that the properties of the hydrogenbonded systems such as the thermodynamic or spectroscopic properties are intimately related to the nature of the proton acceptor $(\mathrm{N}, \mathrm{O}, \mathrm{S})$ [37], and the influence of the basicity/acidity on these properties has been discussed in several works. Much less data are available for halogen bonds. In the present work, we want to discuss the influence of the basicity on the complexes formed between $\mathrm{CClF}_{3}$ and simple carbonyl derivatives $\left(\mathrm{H}_{2} \mathrm{CO}, \mathrm{HFCO}, \mathrm{F}_{2} \mathrm{CO}\right.$, $\left.\mathrm{CH}_{3} \mathrm{CHO}, \mathrm{CH}_{3} \mathrm{CFO},\left(\mathrm{CH}_{3}\right)_{2} \mathrm{CO}\right)$ where different substitutions allow to modulate the electron donor ability. With the exception of the $\mathrm{H}_{2} \mathrm{CO} \cdots \mathrm{ClCF}_{3}$ complex $[27,28,36]$, no theoretical data have been reported for these systems.

The present work is arranged as follows. In the first part, the structure of the complexes, the binding energies and the variation of the $\mathrm{C}-\mathrm{Cl}$ and $\mathrm{C}-\mathrm{F}$ bond lengths are discussed. The second part deals with the NBO (natural bond orbital) analysis, focusing mainly on the occupation of bonding and antibonding orbitals, the hybridization of the $\mathrm{C}$ atom and inter- and intramolecular stabilization energies. The results of SAPT calculations are presented as well. In the last part of our work, the frequency shifts of the $v(\mathrm{C}-\mathrm{Cl})$ and $v(\mathrm{C}-\mathrm{F})$ stretching vibrations induced by the interaction with ketones are discussed.

\section{Computational methods}

The optimized geometries, vibrational harmonic frequencies and infrared intensities have been calculated for the following six carbonyl bases: $\mathrm{H}_{2} \mathrm{C}=\mathrm{O} ; \mathrm{HFC}=\mathrm{O} ; \mathrm{F}_{2} \mathrm{C}=\mathrm{O}$; $\mathrm{CH}_{3} \mathrm{HC}=\mathrm{O} ; \mathrm{CH}_{3} \mathrm{FC}=\mathrm{O}$ and $\left(\mathrm{CH}_{3}\right)_{2} \mathrm{C}=\mathrm{O}$. Then, full geometry optimization and the calculations of the vibrational properties have been performed for the complexes of these bases with $\mathrm{CClF}_{3}$. In the calculations, we employed an ab initio MP2 method [38] combined with the cc-pVTZ basis set [39], as well as the B3LYP [40, 41], B3LYP-D3 (which is B3LYP corrected with the original D3 damping function) [42] and wB97XD [43] hybrid density functionals combined with the $6-311++\mathrm{G}(\mathrm{d}, \mathrm{p})$ basis set $[44,45]$. The counterpoise $\mathrm{CP}$-corrected gradient optimization has been used in the MP2 calculations [46].

The interaction energies of the studied complexes have been determined at the MP2/aug-cc-pVTZ, $\operatorname{CCSD}(\mathrm{T}) /$
aug-cc-pVTZ, B3LYP/6-311++G(d,p), B3LYP-D3/6$311++\mathrm{G}(\mathrm{d}, \mathrm{p})$ and $\mathrm{wB} 97 \mathrm{XD} / 6-311++\mathrm{G}(\mathrm{d}, \mathrm{p})$ levels of theory. In the calculations of the interaction energies by two ab initio methods [MP2 and $\operatorname{CCSD}(\mathrm{T})]$ coupled with the aug-cc-pVTZ basis set, we have used the geometry of the complexes optimized at the MP2/cc-pVTZ level. All the interaction energies were corrected for the basis set superposition error (BSSE) computed by the CP method [46].

For all the complexes, the symmetry-adapted perturbation theory (SAPT) decomposition of the interaction energies has been performed at the MP2/cc-pVTZ level of theory. All the computations were carried out with the Gaussian 09 [47] or MOLPRO 2012 [48] programs.

A natural bond orbital (NBO) analysis provides a detailed insight into the nature of electronic structure and bonding in the molecules. In this work, the atomic charges, hybridization, occupation of orbitals and the second-order interaction energies were calculated by the DFT method using the 5.0 version of the NBO program $[49,50]$. The atoms in molecules (AIM) analysis [51] was used in order to characterize the intermolecular interactions between the carbonyl bases and chlorotrifluoromethane investigated in this work.

\section{Results and discussion}

\subsection{Structures of the complexes and interaction energies}

The structures of the interacting molecules optimized with the MP2 method are illustrated in Fig. 1. Intermolecular parameters $(\mathrm{O} \cdots \mathrm{Cl}$ distances, $\mathrm{CO} \cdots \mathrm{Cl}$ and $\mathrm{CCl} \cdots \mathrm{O}$ angles) are indicated in Table 1. In all the systems, the intermolecular $\mathrm{O} \cdots \mathrm{Cl}$ distances are all smaller than the sum of the van der Waals radii $(3.27 \AA)$.

At any level of theory, the $\mathrm{O} \cdots \mathrm{Cl}$ distance is the longest in the $\mathrm{F}_{2} \mathrm{C}=\mathrm{O}$ complex; these distances in the $\mathrm{CH}_{3} \mathrm{CHO}$ and $\left(\mathrm{CH}_{3}\right)_{2} \mathrm{CO}$ complexes are nearly equal, being slightly longer in the first system when considering the MP2, B3LYP and B3LYP-D3 calculations. As in the case of the complexes between molecular chlorine and the same carbonyl bases, the asymmetrical ketones show two different structures where the $\mathrm{C}-\mathrm{Cl}$ bond coincides approximately with the direction of the lone-pair orbitals of the oxygen atom (O LPs) $[52,53]$. The $\mathrm{C}-\mathrm{Cl} \cdots \mathrm{O}$ bonds calculated at the B3LYP level are nearly linear and show larger departures from linearity when calculated at other levels. It follows from the $\mathrm{H} \cdots \mathrm{Cl}$ distances that there is no bond formation between the $\mathrm{C}-\mathrm{H}$ group of the ketones and the $\mathrm{Cl}$ atom of $\mathrm{CClF}_{3}$. However, a weak interaction between the $\mathrm{H}$ and $\mathrm{Cl}$ atoms cannot be ruled out in the $\mathrm{CH}_{3} \mathrm{CFO}(\mathrm{b})$ and $\left(\mathrm{CH}_{3}\right)_{2} \mathrm{CO}$ complexes. 
Fig. 1 Structures of $\mathrm{CClF}_{3}$ complexes with carbonyl bases optimized at the MP2/cc-pVTZ level

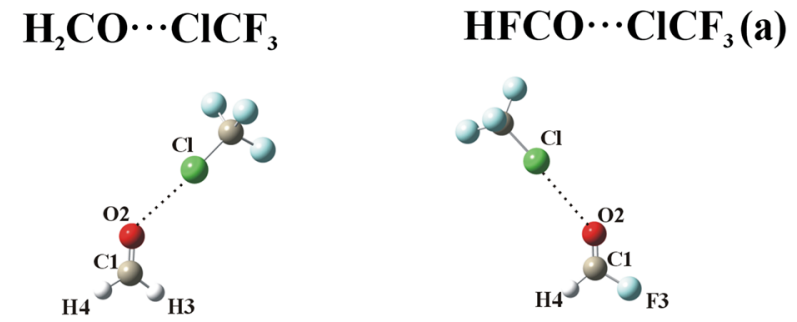

$\mathrm{HFCO}_{\cdots \mathrm{CICF}_{3}(\mathrm{~b})}$

$\mathrm{F}_{2} \mathrm{CO} \cdots \mathrm{ClCF}_{3}$

$\mathrm{CH}_{3} \mathrm{CHO} \cdot \mathrm{ClCF}_{3}$ (a)
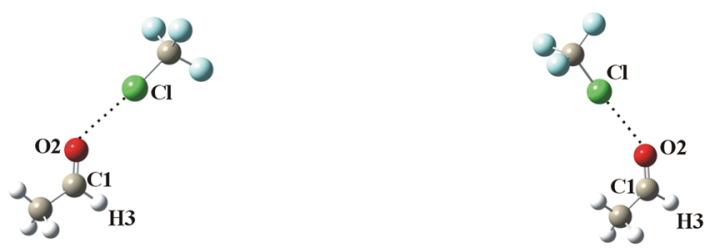

$\mathrm{CH}_{3} \mathrm{CFO} \cdots \mathrm{ClCF}_{3}$ (a) $\mathrm{CH}_{3} \mathrm{CFO} \cdot \mathrm{ClCF}_{3}$ (b)

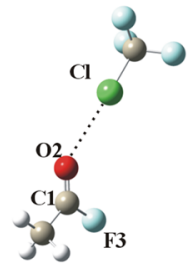

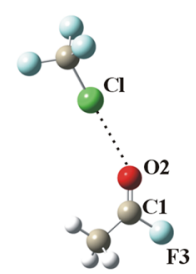

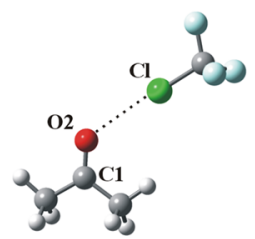

Table 1 Intermolecular parameters (distances in $\AA$, angles in degrees) in the systems formed between substituted carbonyl bases and $\mathrm{CClF}_{3}$ calculated at different levels of theory (A, B, C and D)

\begin{tabular}{|c|c|c|c|c|c|c|c|c|c|c|c|c|}
\hline \multirow[t]{2}{*}{ System } & \multicolumn{4}{|c|}{$\mathrm{R}\left(\mathrm{O}_{2} \cdots \mathrm{Cl}\right)$} & \multicolumn{4}{|c|}{$<\mathrm{C}_{1}-\mathrm{O}_{2} \cdots \mathrm{Cl}$} & \multicolumn{4}{|c|}{$<\mathrm{C}-\mathrm{Cl} \cdots \mathrm{O}_{2}$} \\
\hline & A & B & $\mathrm{C}$ & $\mathrm{D}$ & A & B & $\mathrm{C}$ & $\mathrm{D}$ & A & B & $\mathrm{C}$ & $\mathrm{D}$ \\
\hline $\mathrm{H}_{2} \mathrm{CO} \cdots \mathrm{ClCF}_{3}$ & 3.082 & 3.050 & 3.068 & 3.017 & 103.5 & 105.3 & 136.3 & 101.7 & 168.7 & 166.3 & 179.1 & 165.7 \\
\hline $\mathrm{HFCO} \cdots \mathrm{ClCF}_{3}$ (a) & 3.178 & 3.163 & 3.183 & 3.133 & 124.4 & 108.9 & 143.3 & 98.6 & 174.2 & 166.0 & 175.6 & 162.5 \\
\hline $\mathrm{HFCO} \cdots \mathrm{ClCF}_{3}(\mathrm{~b})$ & 3.167 & 3.184 & 3.185 & 3.108 & 141.4 & 123.8 & 152.1 & 126.4 & 178.8 & 176.2 & 178.4 & 178.6 \\
\hline $\mathrm{F}_{2} \mathrm{CO} \cdots \mathrm{ClCF}_{3}$ & 3.184 & 3.285 & 3.240 & 3.128 & 160.3 & 116.5 & 167.5 & 164.6 & 179.9 & 167.3 & 179.7 & 179.0 \\
\hline $\mathrm{CH}_{3} \mathrm{CHO} \cdots \mathrm{ClCF}_{3}$ (a) & 3.047 & 2.995 & 3.018 & 2.977 & 104.6 & 106.5 & 135.8 & 103.0 & 170.2 & 168.2 & 179.8 & 167.8 \\
\hline $\mathrm{CH}_{3} \mathrm{CHO} \cdots \mathrm{ClCF}_{3}(\mathrm{~b})$ & 3.083 & 3.062 & 3.042 & 3.010 & 127.4 & 123.6 & 142.9 & 121.6 & 177.5 & 173.8 & 179.8 & 174.9 \\
\hline $\mathrm{CH}_{3} \mathrm{CFO} \cdots \mathrm{ClCF}_{3}$ (a) & 3.136 & 3.087 & 3.131 & 3.068 & 130.4 & 125.6 & 141.4 & 121.5 & 178.8 & 178.6 & 179.9 & 179.3 \\
\hline $\mathrm{CH}_{3} \mathrm{CFO} \cdots \mathrm{ClCF}_{3}(\mathrm{~b})$ & 3.130 & 3.117 & 3.115 & 3.073 & 121.0 & 118.7 & 148.6 & 115.7 & 172.6 & 167.3 & 176.8 & 168.4 \\
\hline$\left(\mathrm{CH}_{3}\right)_{2} \mathrm{CO} \cdots \mathrm{ClCF}_{3}$ & 2.994 & 3.002 & 3.003 & 2.968 & 126.0 & 125.4 & 148.0 & 124.3 & 178.1 & 174.3 & 178.7 & 176.8 \\
\hline
\end{tabular}

The structures (a) and (b) are shown in Fig. 1

A MP2/cc-pVTZ, B wB97XD/6-311++G(d,p), C B3LYP/6-311++G(d,p), D B3LYP-D3/6-311++G(d,p)

According to the AIM theory, two atoms are bonded to each other if their nuclei are linked by a line of maximal electron density named the bond path. Figure 2 demonstrates the presence of a bond critical point (BCP) in the $\mathrm{H}_{2} \mathrm{CO} \cdots \mathrm{ClCF}_{3}$ complex. The electron density $(\rho)$, the Laplacian of the electron density $\left(\nabla^{2} \rho\right)$ and the total electron energy $(\mathrm{H})$ at the selected $\mathrm{BCP}$ in all the studied complexes are collected in Table 2. 


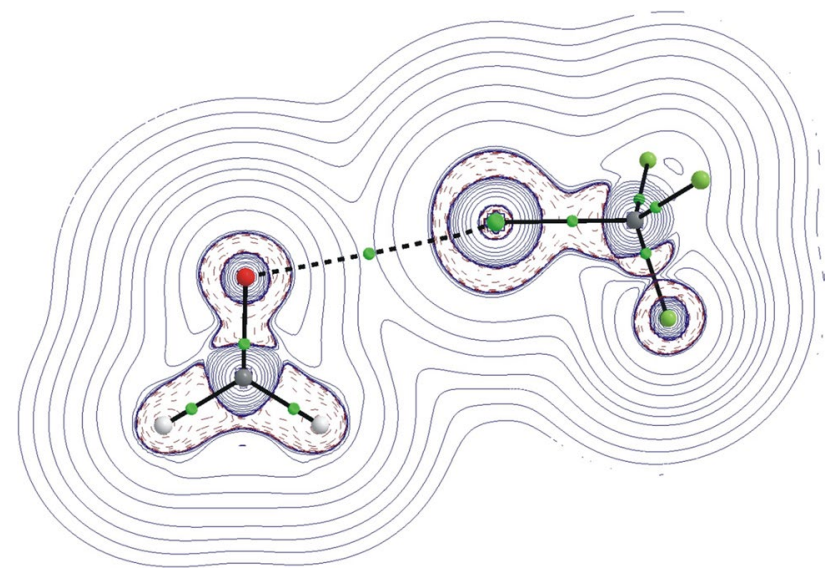

Fig. 2 Contour line diagram of the Laplacian of the electron density of the $\mathrm{H}_{2} \mathrm{CO} \cdots \mathrm{ClCF}_{3}$ complex (in the plane passing through the $\mathrm{O}$, $\mathrm{Cl}$ and $\mathrm{C}$ atoms marked on the figure). The solid (blue) lines represent negative values of the Laplacian, while the dashed (red) lines represent the positive values. The electron density description was obtained at the MP2/cc-pVTZ level

Table 2 Bond critical points (BCP) properties: electron density $\rho$, Laplacian of electron density $\nabla^{2} \rho$ (both in atomic units) and total electron energy $\left(\mathrm{H}, \mathrm{kcal} \mathrm{mol}^{-1}\right)$

\begin{tabular}{lllll}
\hline System & Interaction & $P$ & $\nabla^{2} \rho$ & $\mathrm{H}$ \\
\hline $\mathrm{H}_{2} \mathrm{CO} \cdots \mathrm{CF}_{3} \mathrm{Cl}$ & $\mathrm{O} \cdots \mathrm{Cl}$ & 0.0088 & 0.0358 & 1.079 \\
$\mathrm{HFCO} \cdots \mathrm{CF}_{3} \mathrm{Cl}(\mathrm{a})$ & $\mathrm{O} \cdots \mathrm{Cl}$ & 0.0064 & 0.0274 & 0.953 \\
$\mathrm{HFCO} \cdots \mathrm{CF}_{3} \mathrm{Cl}(\mathrm{b})$ & $\mathrm{O} \cdots \mathrm{Cl}$ & 0.0062 & 0.0276 & 0.987 \\
$\mathrm{~F}_{2} \mathrm{CO} \cdots \mathrm{CF}_{3} \mathrm{Cl}$ & $\mathrm{O} \cdots \mathrm{Cl}$ & 0.0055 & 0.0258 & 0.980 \\
$\mathrm{CH}_{3} \mathrm{CHO} \cdots \mathrm{CF}_{3} \mathrm{Cl}(\mathrm{a})$ & $\mathrm{O} \cdots \mathrm{Cl}$ & 0.0095 & 0.0386 & 1.158 \\
$\mathrm{CH}_{3} \mathrm{CHO} \cdots \mathrm{CF}_{3} \mathrm{Cl}(\mathrm{b})$ & $\mathrm{O} \cdots \mathrm{Cl}$ & 0.0083 & 0.0346 & 1.106 \\
$\mathrm{CH}_{3} \mathrm{CFO} \cdots \mathrm{CF}_{3} \mathrm{Cl}(\mathrm{a})$ & $\mathrm{O} \cdots \mathrm{Cl}$ & 0.0069 & 0.0300 & 1.044 \\
$\mathrm{CH}_{3} \mathrm{CFO} \cdots \mathrm{CF}_{3} \mathrm{Cl}(\mathrm{b})$ & $\mathrm{O} \cdots \mathrm{Cl}$ & 0.0073 & 0.0310 & 1.045 \\
& $\mathrm{H} \cdots \mathrm{Cl}$ & 0.0030 & 0.0111 & 0.432 \\
$\left(\mathrm{CH}_{3}\right)_{2} \mathrm{CO} \cdots \mathrm{CF}_{3} \mathrm{Cl}$ & $\mathrm{O} \cdots \mathrm{Cl}$ & 0.0101 & 0.0429 & 1.324 \\
& $\mathrm{H} \cdots \mathrm{Cl}$ & 0.0037 & 0.0137 & 0.518 \\
\hline
\end{tabular}

The electron density descriptions were obtained at the MP2/cc-pVTZ level

As indicated in Table 2, in the case of two complexes: $\mathrm{CH}_{3} \mathrm{CFO} \cdots \mathrm{ClCF}_{3}$ (b) and $\left(\mathrm{CH}_{3}\right)_{2} \mathrm{CO} \cdots \mathrm{ClCF}_{3}$, the AMI calculations suggest an additional stabilization interaction between the chlorine and hydrogen atoms $(\mathrm{H} \cdots \mathrm{Cl})$. According to the Popelier's criteria for hydrogen bonds, the electron density at the BCP ranges from 0.002 to $0.035 \mathrm{au}$, and the Laplacian of the electron density ranges from 0.024 to 0.139 au $[54,55]$. As follows from Table 2, these two $\mathrm{H} \cdots \mathrm{Cl}$ interactions do not fulfill the second criterion. Therefore, they cannot be classified as hydrogen bonds but as weak van der Waals interactions. It is worth to mention that in both the $\mathrm{CH}_{3} \mathrm{CFO} \cdots \mathrm{ClCF}_{3}$ (b) and $\left(\mathrm{CH}_{3}\right)_{2} \mathrm{CO} \cdots \mathrm{ClCF}_{3}$ complexes, the $\mathrm{H} \cdots \mathrm{Cl}$ distances are longer than the sum of the corresponding van der Waals radii by 0.29 and $0.20 \AA$, respectively.

When considering only the $\mathrm{O} \cdots \mathrm{Cl}$ interactions, we have found the following correlations between the B3LYP-D3 binding energies and the AMI parameters $\left(\rho\right.$ and $\left.\nabla^{2} \rho\right)$ :

$$
\begin{aligned}
& -\Delta E=285.1(\rho)-0.27 \quad\left(r^{2}=0.911\right) \\
& -\Delta E=2.66 \ln \left(\nabla^{2} \rho\right)+11.04 \quad\left(r^{2}=0.931\right)
\end{aligned}
$$

The interaction energies calculated at different levels are reported in Table 3. The values of the energies calculated with the wB97XD and B3LYP methods are lower than the ones calculated by the other methods. The values obtained at the B3LYP-D3, MP2 and CCSD(T) levels of theory are similar. Let us notice that the interaction energy for the $\mathrm{H}_{2} \mathrm{CO} \cdots \mathrm{ClCF}_{3}$ system calculated in Ref. [29] at the MP2(full)/6-311++G(3df, 3pd) level is equal to $-1.90 \mathrm{kcal} \mathrm{mol}^{-1}$, which is by $0.3 \mathrm{kcal} \mathrm{mol}^{-1}$ lower than our B3LYP-D3 calculated value.

At each level of theory, larger intermolecular $\mathrm{O} \cdots \mathrm{Cl}$ distances result in lower interaction energies, and in the further discussion, we will consider the B3LYP-D3 interaction energies.

As indicated in Table 3, the electron-releasing $\mathrm{CH}_{3}$ group strengthens the interaction and the electron-attracting substituents weaken the interaction. This prompted us to compare the interaction energies with the basic properties of the ketones. The proton affinities (PA) calculated at the B3LYP-D3/6-311++G(d,p) level as well as the calculated and experimental ionization potentials (IP) of the ketones [56-61] are reported in Table 4.

From the B3LYP-D3 energies, we have calculated the following correlations:

$$
-\Delta E\left(\mathrm{kcal} \mathrm{mol}^{-1}\right)=-0.470 \mathrm{IP}(\mathrm{eV})+7.325 \quad\left(r^{2}=0.982\right)
$$

$$
\begin{aligned}
-\Delta E\left(\mathrm{kcal} \mathrm{mol}^{-1}\right)= & -0.034 \mathrm{PA}\left(\mathrm{kcal} \mathrm{mol}^{-1}\right) \\
& -3.992 \quad\left(r^{2}=0.950\right)
\end{aligned}
$$

The correlation 3 is illustrated in Fig. 3. The slopes of these two correlations are much lower than those recently reported for the stronger complexes between the same carbonyl bases and molecular chlorine $(-0.76$ and 0.055 , respectively) [52].

Comparison with the literature values is difficult. The reported interaction energy in the $\mathrm{NH}_{3} \cdots \mathrm{ClCF}_{3}$ system is equal to $-2.37 \mathrm{kcal} \mathrm{mol}^{-1}$ (MP2/aug-cc-pVDZ) [21, 22]. The PA of $\mathrm{NH}_{3}$ is $204 \mathrm{kcal} \mathrm{mol}^{-1}$, about the same as that 
Table 3 Interaction energies (AE, $\mathrm{kcal} \mathrm{mol}^{-1}$ ) of $\mathrm{CF}_{3} \mathrm{Cl}$ complexes with carbonyl bases calculated at different levels of theory (corrected for BSSE)

\begin{tabular}{|c|c|c|c|c|c|}
\hline \multirow[t]{2}{*}{ System } & \multicolumn{5}{|l|}{$\mathrm{AE}$} \\
\hline & wB97XD ${ }^{a}$ & $\mathrm{~B}_{3} \mathrm{LYP}^{\mathrm{b}}$ & B3LYP-D3 $^{\mathrm{a}}$ & $\mathrm{MP} 2^{\mathrm{b}}$ & $\operatorname{CCSD}(\mathrm{T})^{\mathrm{b}}$ \\
\hline $\mathrm{H}_{2} \mathrm{CO} \cdots \mathrm{C} 1 \mathrm{CF}_{3}$ & -1.50 & -1.42 & -2.21 & -2.07 & -2.03 \\
\hline $\mathrm{HFCO} \cdots \mathrm{C} 1 \mathrm{CF}_{3}$ (a) & -1.00 & -0.67 & -1.56 & -1.43 & -1.43 \\
\hline $\mathrm{HFCO} \cdots \mathrm{CICF}_{3}(\mathrm{~b})$ & -1.00 & -0.71 & -1.48 & -1.47 & -1.47 \\
\hline $\mathrm{F}_{2} \mathrm{CO} \cdots \mathrm{CICF}_{3}$ & -0.77 & -0.48 & -1.14 & -1.24 & -1.22 \\
\hline $\mathrm{CH}_{3} \mathrm{CHO} \cdots \mathrm{CICF}_{3}$ (a) & -1.82 & -1.42 & -2.55 & -2.37 & -2.36 \\
\hline $\mathrm{CH}_{3} \mathrm{CHO} \cdots \mathrm{CICF}_{3}(\mathrm{~b})$ & -1.87 & -1.33 & -2.50 & -2.33 & -2.31 \\
\hline $\mathrm{CH}_{3} \mathrm{CFO} \cdots \mathrm{CICF}_{3}$ (a) & -1.31 & -0.96 & -1.82 & -1.79 & -1.81 \\
\hline $\mathrm{CH}_{3} \mathrm{CFO} \cdots \mathrm{CICF}_{3}(\mathrm{~b})$ & -1.50 & -0.88 & -2.08 & -2.00 & -1.98 \\
\hline$\left(\mathrm{CH}_{3}\right) 2 \mathrm{CO} \cdots \mathrm{ClCF}_{3}$ & -2.13 & -1.55 & -2.81 & -2.63 & -2.62 \\
\hline
\end{tabular}

The structures (a) and (b) are shown in Fig. 1

a Method combined with the 6-311++G(d,p) basis set

b Method combined with the aug-cc-pVTZ basis set
Table 4 Proton affinities (PA, $\mathrm{kcal} \mathrm{mol}^{-1}$ ) and calculated and experimental ionization potentials (IP, eV) of the carbonyl bases, calculated at the B3LYP-D3/6-311++G(d,p) level of theory

\begin{tabular}{llll}
\hline Base & PA (B3LYP-D3) & IP (B3LYP-D3) & IP exp \\
\hline $\mathrm{H}_{2} \mathrm{CO}$ & 177.5 & 10.90 & $10.89^{\mathrm{a}}$ \\
$\mathrm{HFCO}$ & $163.9^{\mathrm{b}}$ & 12.40 & $12.37^{\mathrm{c}}$ \\
& 162.7 & & \\
$\mathrm{~F}_{2} \mathrm{CO}$ & 154.1 & 13.03 & $13.04^{\mathrm{d}}$ \\
$\mathrm{CH}_{3} \mathrm{CHO}$ & 192.9 & 10.17 & $10.23^{\mathrm{e}}$ \\
$\mathrm{CH}_{3} \mathrm{CFO}$ & 192.3 & & \\
& 179.5 & 11.47 & $11.51^{\mathrm{f}}$ \\
$\left(\mathrm{CH}_{3}\right)_{2} \mathrm{CO}$ & 177.3 & & $9.67^{\mathrm{g}}$ \\
\hline
\end{tabular}

${ }^{\mathrm{a}}$ From Ref. [57]. ${ }^{\mathrm{b}}$ The two values refer to cis and trans protonation. ${ }^{\mathrm{c}}$ From Ref. [58]. ${ }^{\mathrm{d}}$ From Ref. [59]. ${ }^{\mathrm{e}}$ From Ref. [60]. ${ }^{\mathrm{f}}$ From Ref. [61]. ${ }^{\mathrm{g}}$ From Ref. [62]

of $\left(\mathrm{CH}_{3}\right)_{2} \mathrm{CO}, 203.5 \mathrm{kcal} \mathrm{mol}^{-1}$ (see Table 4), and the $\triangle \mathrm{E}$ of the $\left(\mathrm{CH}_{3}\right)_{2} \mathrm{CO} \cdots \mathrm{ClCF}_{3}$ complex (calculated at the MP2/aug-cc-pVTZ level of theory) is $-2.63 \mathrm{kcal} \mathrm{mol}^{-1}$, as shown in Table 3. The interaction energy in the $\mathrm{H}_{2} \mathrm{O} \cdots \mathrm{ClCF}_{3}$ system is equal to $-1.46 \mathrm{kcal} \mathrm{mol}^{-1}$ (MP2/ccpVTZ) [26] or $-1.76 \mathrm{kcal} \mathrm{mol}^{-1}$ [MP2/6-311++G(d,p)] [24], the PA of $\mathrm{H}_{2} \mathrm{O}$ being equal to $166.5 \mathrm{kcal} \mathrm{mol}^{-1}$. In the $\mathrm{H}_{2} \mathrm{CO} \cdots \mathrm{ClCF}_{3}$ complex, the interaction energy is larger $\left(-2.07 \mathrm{kcal} \mathrm{mol}^{-1}\right)$, and this is consistent with the fact that the value of the PA of $\mathrm{H}_{2} \mathrm{CO}\left(177.5 \mathrm{kcal} \mathrm{mol}^{-1}\right.$, Table 4) is larger than that of $\mathrm{H}_{2} \mathrm{O}$ by $11 \mathrm{kcal} \mathrm{mol}^{-1}$.

As outlined in several works [21, 24, 25, 28] when $\mathrm{CClF}_{3}$ interacts with electron donors of medium strength such as $\mathrm{NH}_{3}, \mathrm{H}_{2} \mathrm{O}$ or $\mathrm{H}_{2} \mathrm{~S}$, the $\mathrm{C}-\mathrm{Cl}$ bond is contracted by moderate amounts. In the $\mathrm{F}_{3} \mathrm{CCl} \cdots \mathrm{NH}_{3}$ system, the $\mathrm{C}-\mathrm{Cl}$ bond is contracted by $6.6 \mathrm{~m} \AA$ [24] or $6.3 \mathrm{~m} \AA$ [21]. In the $\mathrm{F}_{3} \mathrm{CCl} \cdots \mathrm{OH}^{-}$system, the $\mathrm{C}-\mathrm{Cl}$ bond is contracted by $7 \mathrm{~m} \AA$

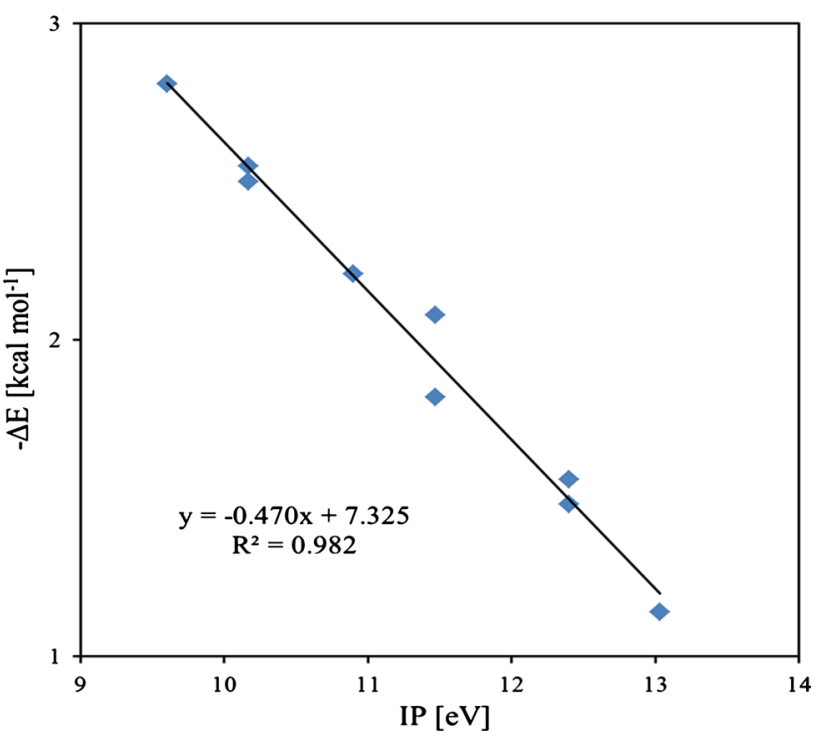

Fig. 3 Interaction energy $-\Delta \mathrm{E}\left(\mathrm{kcal} \mathrm{mol}^{-1}\right)$ as a function of the ionization potential $\mathrm{IP}(\mathrm{eV})$

[24], and in the weaker $\mathrm{F}_{3} \mathrm{CCl} \cdots \mathrm{SH}_{2}$ complex, the $\mathrm{C}-\mathrm{Cl}$ bond is contracted by only $2.9 \mathrm{~m} \AA$ [25].

The values of the $\mathrm{C}-\mathrm{Cl}$ bond contraction for the present systems are reported in Table 5 which also indicates the elongation of the three $\mathrm{CF}$ bonds. These results show that the contraction of the $\mathrm{C}-\mathrm{Cl}$ bond is moderate, ranging from $4.7 \mathrm{~m} \AA$ in $\mathrm{F}_{2} \mathrm{CO}$ to $9.4 \mathrm{~m} \AA$ in $\left(\mathrm{CH}_{3}\right)_{2} \mathrm{CO}$. As in general, bond contractions are connected with blue shifts of the corresponding stretching frequency, the present complexes can be categorized as blue-shifting complexes. Further, the elongation of the $\mathrm{C}-\mathrm{F}$ bonds is comprised between 1.6 and $5.1 \mathrm{~m} \AA$ and is also the largest in the complexed $\left(\mathrm{CH}_{3}\right)_{2} \mathrm{CO}$ system. 
Table 5 Variation of the $\mathrm{C}-\mathrm{Cl}$ and $\mathrm{C}-\mathrm{F}$ distances $(\mathrm{m} \AA$ ) in the complexes between $\mathrm{CClF}_{3}$ and carbonyl derivatives

\begin{tabular}{lll}
\hline System & $\Delta r(\mathrm{C}-\mathrm{Cl})^{\mathrm{a}}$ & $\Delta r(\mathrm{C}-\mathrm{F})^{\mathrm{b}}$ \\
\hline $\mathrm{H}_{2} \mathrm{CO} \cdots \mathrm{ClCF}_{3}$ & $-7.0^{\mathrm{c}}$ & $+1.8,+2.8,+2.8$ \\
$\mathrm{HFCO} \cdots \mathrm{ClCF}_{3}(\mathrm{a})$ & -5.1 & $+2.9,+2.4,+1.6$ \\
$\mathrm{HFCO} \cdots \mathrm{ClCF}_{3}(\mathrm{~b})$ & -6.3 & $+2.6,+2.6,+2.7$ \\
$\mathrm{~F}_{2} \mathrm{CO} \cdots \mathrm{ClCF}_{3}$ & -4.7 & $+1.9,+1.9,+2.1$ \\
$\mathrm{CH}_{3} \mathrm{CHO} \cdots \mathrm{ClCF}_{3}(\mathrm{a})$ & -8.2 & $+3.8,+3.8,+4.8$ \\
$\mathrm{CH}_{3} \mathrm{CHO} \cdots \mathrm{ClCF}_{3}(\mathrm{~b})$ & -8.2 & $+3.1,+4.1,+4.1$ \\
$\mathrm{CH} 3 \mathrm{CFO} \cdots \mathrm{ClCF}_{3}(\mathrm{a})$ & -7.0 & $+3.4,+3.4,+3.4$ \\
$\mathrm{CH}_{3} \mathrm{CFO} \cdots \mathrm{ClCF}_{3}(\mathrm{~b})$ & -6.5 & $+2.7,+2.2,+3.9$ \\
$\left(\mathrm{CH}_{3}\right)_{2} \mathrm{CO} \cdots \mathrm{ClCF}_{3}$ & -9.4 & $+4.0,+5.1,+4.6$ \\
\hline
\end{tabular}

a $r(\mathrm{C}-\mathrm{Cl})$ in isolated $\mathrm{CClF}_{3}=1.7730 \AA .{ }^{\mathrm{b}} r(\mathrm{C}-\mathrm{F})$ in isolated $\mathrm{CClF}_{3}=1.3328 \AA .{ }^{\mathrm{c}}$ Contraction of the $\mathrm{C}-\mathrm{Cl}$ bond reported in Ref. $[28]=6 \mathrm{~m} \AA$

\subsection{NBO analysis}

In this section, we want to discuss the results of a $\mathrm{NBO}$ analysis, focusing mainly on the NBO charges, the occupation of bonding and antibonding orbitals, the hybridization of the $\mathrm{C}$ atom along with the second-order inter- and intramolecular stabilization energies.

Let us remember that halogen bonds have been compared to hydrogen bonds and have been shown to be similar in many aspects [63-67]. Briefly summarizing, let us mention that the contraction of a $\mathrm{Z}-\mathrm{H}$ bond in a hydrogenbonded system $\mathrm{ZH} \cdots \mathrm{Y}$ has been explained mainly by a variation of the $\sigma^{*}(\mathrm{C}-\mathrm{H})$ occupation and a change in the hybridization of the $\mathrm{Z}(\mathrm{H})$ atom [68-74]. These parameters can also be discussed for the blue-shifting halogen bonds. The results of our NBO analysis for the present systems are presented in Tables 6, 7 and 8 .

The variation of the NBO charges on the $\mathrm{C}$ and $\mathrm{Cl}$ atoms of $\mathrm{CClF}_{3}$ induced by the interaction with the ketones is indicated in Table 6 . This table also reports the variation of hybridization of the $\mathrm{C}$ atom in the $\mathrm{C}(\mathrm{Cl})$ and $\mathrm{C}(\mathrm{F})$ bonds along with the global charge transfer (CT) occurring from the ketones to $\mathrm{CClF}_{3}$. Table 7 reports the second-order stabilization energies $E^{(2)} \rightarrow \sigma^{*}(\mathrm{C}-\mathrm{Cl})$, the occupation of the $\sigma^{*}(\mathrm{C}-\mathrm{Cl})$ antibonding and $\sigma(\mathrm{C}-\mathrm{Cl})$ bonding orbitals. In Table 8, the intramolecular charge transfer energies from the lone-pair orbitals (LPs) of the three F atoms to the
Table 6 NBO charges (e) on the $\mathrm{C}, \mathrm{Cl}$ and $\mathrm{F}$ atoms, \% $s$-character of the $\mathrm{C}(\mathrm{Cl})$ and $\mathrm{C}(\mathrm{F})$ atoms in isolated and complexed $\mathrm{CClF}_{3}$ and charge transfer $(\mathrm{CT}, \mathrm{me})$

\begin{tabular}{|c|c|c|c|c|c|}
\hline & $q(\mathrm{C})$ & $q(\mathrm{Cl})$ & $\% s \mathrm{C}(\mathrm{Cl})$ & $q(\mathrm{~F})^{\mathrm{a}}$ & $\% s \mathrm{C}(\mathrm{F})^{\mathrm{a}}$ \\
\hline $\mathrm{CClF}_{3}$ & 1.0060 & -0.0037 & $26.16^{\mathrm{b}}$ & -0.3341 & 24.63 \\
\hline $\begin{array}{l}\mathrm{H}_{2} \mathrm{CO} \cdots \mathrm{ClCF}_{3} \\
\mathrm{CT}=4.2 \mathrm{me}^{\mathrm{a}}\end{array}$ & $\begin{array}{l}0.9949 \\
(+11.1)\end{array}$ & $\begin{array}{l}0.0200 \\
(-23.37)\end{array}$ & $\begin{array}{l}26.86^{\mathrm{b}} \\
(+0.70)\end{array}$ & $\begin{array}{l}-0.3407(+6.6) \\
-0.3392(+5.1) \\
-0.3392(+5.1)\end{array}$ & $\begin{array}{l}24.38(-0.25) \\
24.43(-0.20) \\
24.43(-0.20)\end{array}$ \\
\hline $\begin{array}{l}\mathrm{HFCO} \cdots \mathrm{ClCF}_{3}(\mathrm{a}) \\
\mathrm{CT}=1.3 \mathrm{me}\end{array}$ & $\begin{array}{l}0.9987 \\
(+7.3)\end{array}$ & $\begin{array}{l}0.0131 \\
(-16.8)\end{array}$ & $\begin{array}{l}26.60 \\
(+0.44)\end{array}$ & $\begin{array}{l}-0.3386(+4.5) \\
-0.3377(+3.6) \\
-0.3367(+2.6)\end{array}$ & $\begin{array}{l}24.46(-0.17) \\
24.49(-0.14) \\
24.53(-0.10)\end{array}$ \\
\hline $\begin{array}{l}\mathrm{HFCO} \cdots \mathrm{ClCF}_{3}(\mathrm{~b}) \\
\mathrm{CT}=1.10 \mathrm{me}\end{array}$ & $\begin{array}{l}0.9976 \\
(+8.4)\end{array}$ & $\begin{array}{l}0.0158 \\
(-18.8)\end{array}$ & $\begin{array}{l}26.67 \\
(+0.53)\end{array}$ & $\begin{array}{l}-0.3382(+4.1) \\
-0.3383(+4.2) \\
-0.3383(+4.2)\end{array}$ & $\begin{array}{l}24.48(-0.15) \\
24.48(-0.15) \\
24.47(-0.16)\end{array}$ \\
\hline $\begin{array}{l}\mathrm{F}_{2} \mathrm{CO} \cdots \mathrm{ClCF}_{3} \\
\mathrm{CT}=0.5 \mathrm{me}\end{array}$ & $\begin{array}{l}0.9998 \\
(+6.2)\end{array}$ & $\begin{array}{l}0.0108 \\
(-14.5)\end{array}$ & $\begin{array}{l}26.53 \\
(+0.37)\end{array}$ & $\begin{array}{l}-0.3370(+2.9) \\
-0.3370(+2.9) \\
-0.3372(+3.1)\end{array}$ & $\begin{array}{l}24.52(-0.11) \\
24.52(-0.11) \\
24.52(-0.11)\end{array}$ \\
\hline $\begin{array}{l}\mathrm{CH}_{3} \mathrm{CHO} \cdots \mathrm{ClCF}_{3} \text { (a) } \\
\mathrm{CT}=4.9 \mathrm{me}\end{array}$ & $\begin{array}{l}0.9927 \\
(+13.3)\end{array}$ & $\begin{array}{l}0.0251 \\
(-28.8)\end{array}$ & $\begin{array}{l}26.99 \\
(+0.83)\end{array}$ & $\begin{array}{l}-0.3404(+6.3) \\
-0.3404(+6.3) \\
-0.3418(+7.7)\end{array}$ & $\begin{array}{l}24.39(-0.24) \\
24.38(-0.25) \\
24.34(-0.29)\end{array}$ \\
\hline $\begin{array}{l}\mathrm{CH}_{3} \mathrm{CHO} \cdots \mathrm{ClCF}_{3}(\mathrm{~b}) \\
\mathrm{CT}=3.9 \mathrm{me}\end{array}$ & $\begin{array}{l}0.9931 \\
(+12.9)\end{array}$ & $\begin{array}{l}0.0246 \\
(-28.3)\end{array}$ & $\begin{array}{l}26.96 \\
(+0.80)\end{array}$ & $\begin{array}{l}-0.3394(+5.3) \\
-0 ; 3406(+6.5) \\
-0.3416(+7.5)\end{array}$ & $\begin{array}{l}24.42(-0.19) \\
24.38(-0.20) \\
24.34(-0.21)\end{array}$ \\
\hline $\begin{array}{l}\mathrm{CH}_{3} \mathrm{CFO} \cdots \mathrm{ClCF}_{3}(\mathrm{a}) \\
\mathrm{CT}=2.1 \mathrm{me}\end{array}$ & $\begin{array}{l}0.9952 \\
(+10.8)\end{array}$ & $\begin{array}{l}0.0209 \\
(-24.6)\end{array}$ & $\begin{array}{l}26.82 \\
(+0.66)\end{array}$ & $\begin{array}{l}-0.3394(+5.3) \\
-0.3394(+5.3) \\
-0.3393(+5.2)\end{array}$ & $\begin{array}{l}24.43(-0.20) \\
24.43(-0.20) \\
24.43(-0.20)\end{array}$ \\
\hline $\begin{array}{l}\mathrm{CH}_{3} \mathrm{CFO} \cdots \mathrm{ClCF}_{3}(\mathrm{~b}) \\
\mathrm{CT}=1.3 \mathrm{me}\end{array}$ & $\begin{array}{l}0.9966 \\
(+9.4)\end{array}$ & $\begin{array}{l}0.0182 \\
(-21.9)\end{array}$ & $\begin{array}{l}26.73 \\
(+0.57)\end{array}$ & $\begin{array}{l}-0.3385(+4.4) \\
-0.3376(+3.5) \\
-0.3401(+4.0)\end{array}$ & $\begin{array}{l}24.46(-0.17) \\
24.49(-0.14) \\
24.41(-0.22)\end{array}$ \\
\hline $\begin{array}{l}\left(\mathrm{CH}_{3}\right)_{2} \mathrm{CO} \cdots \mathrm{ClCF}_{3} \\
\mathrm{CT}=4.8 \mathrm{me}\end{array}$ & $\begin{array}{l}0.9891 \\
(+16.9)\end{array}$ & $\begin{array}{l}0.0279 \\
(-31.6)\end{array}$ & $\begin{array}{l}27.08 \\
(+0.92)\end{array}$ & $\begin{array}{l}-0.3397(+5.6) \\
-0.3414(+7.3) \\
-0.3406(+6.5)\end{array}$ & $\begin{array}{l}24.36(-0.27) \\
24.29(-0.34) \\
24.33(-0.30)\end{array}$ \\
\hline
\end{tabular}

The numbers in parentheses indicate the variation of the charges (in me) induced by the interaction

a $\mathrm{CT}=4.8$ me (Ref. [28]). ${ }^{\mathrm{b}} s$-character in isolated $\mathrm{F}_{3} \mathrm{CCl}=26.62 \%$ and in $\mathrm{H}_{2} \mathrm{CO} \cdots \mathrm{ClCF}_{3}=27.27 \%$ (Ref. [28]), giving an increase equal to $0.65 \%$ 
Table 7 Second-order stabilization energies $E^{2}\left[\mathrm{LPsO} \rightarrow \sigma^{*}(\mathrm{C}-\mathrm{Cl})\right]$ $\left(\mathrm{kcal} \mathrm{mol}^{-1}\right), \sigma^{*}(\mathrm{CCl})$ and $\sigma(\mathrm{CCl})$ occupation (e) and variation (in parentheses) induced by the interaction with carbonyl bases (me)

\begin{tabular}{llll}
\hline System & \multicolumn{2}{l}{$\begin{array}{l}E^{2} \\
{\left[\mathrm{LPsO} \rightarrow \sigma^{*}(\mathrm{C}-\mathrm{Cl})\right]}\end{array}$} & $\sigma(\mathrm{C}-\mathrm{Cl})$ \\
\hline $\mathrm{CClF}_{3}$ & - & 0.1197 & 1.9853 \\
$\mathrm{H}_{2} \mathrm{CO} \cdots \mathrm{ClCF}_{3}$ & 0.98 & $0.1083(-11.4)$ & $1.9844(-0.9)$ \\
$\mathrm{HFCO} \cdots \mathrm{ClCF}_{3}$ (a) & 0.58 & $0.1084(-11.3)$ & $1.9845(-0.8)$ \\
$\mathrm{HFCO} \cdots \mathrm{ClCF}_{3}(\mathrm{~b})$ & 0.49 & $0.1076(-12.1)$ & $1.9846(-0.7)$ \\
$\mathrm{F}_{2} \mathrm{CO} \cdots \mathrm{ClCF}_{3}$ & 0.30 & $0.1083(-11.4)$ & $1.9847(-0.6)$ \\
$\mathrm{CH}_{3} \mathrm{CHO} \cdots \mathrm{ClCF}_{3}(\mathrm{a})$ & 1.24 & $0.1080(-11.7)$ & $1.9842(-0.11)$ \\
$\mathrm{CH}_{3} \mathrm{CHO} \cdots \mathrm{ClCF}_{3}(\mathrm{~b})$ & 1.02 & $0.1076(-12.1)$ & $1.9842(-0.11)$ \\
$\mathrm{CH}_{3} \mathrm{CFO} \cdots \mathrm{ClCF}_{3}$ (a) & 0.69 & $0.1071(-12.6)$ & $1.9843(-0.10)$ \\
$\mathrm{CH}_{3} \mathrm{CFO} \cdots \mathrm{ClCF}_{3}$ (b) & 0.68 & $0.1075(-12.2)$ & $1.9843(-0.10)$ \\
$\left(\mathrm{CH}_{3}\right)_{2} \mathrm{CO} \cdots \mathrm{ClCF}_{3}$ & 1.04 & $0.1070(-12.7)$ & $1.9943(-0.10)$ \\
\hline
\end{tabular}

Table 8 Second-order stabilization energies $E^{2}$ [LPF $\left.\rightarrow \sigma *(\mathrm{C}-\mathrm{Cl})\right]$ $\left(\mathrm{kcal} \mathrm{mol}^{-1}\right.$ ) and $\sigma^{*}(\mathrm{CF})$ occupation (e) and variation in parentheses (me)

\begin{tabular}{llr}
\hline system & $E^{2}\left[\mathrm{LPF} \rightarrow \sigma^{*}(\mathrm{C}-\mathrm{Cl})\right]$ & $\sigma^{*}(\mathrm{C}-\mathrm{F})$ \\
\hline $\mathrm{CClF}_{3}$ & 37.11 & 0.1121 \\
$\mathrm{H}_{2} \mathrm{CO} \cdots \mathrm{ClCF}_{3}$ & $35.50(-1.51)$ & $0.1139(1.8), 0.1133$ \\
& & $(1.2), 0.1133(1.2)$ \\
$\mathrm{HFCO} \cdots \mathrm{ClCF}_{3}$ (a) & $35.97(-1.14)$ & $0.1134(1.3), 0.1131$ \\
& & $(1.0), 0.1127(0.6)$ \\
$\mathrm{HFCO} \cdots \mathrm{ClCF}_{3}$ (b) & $35.88(-1.23)$ & $0.1133(1.2), 0.1133$ \\
& & $(1.2), 0.1134(1.3)$ \\
$\mathrm{F}_{2} \mathrm{CO} \cdots \mathrm{ClCF}_{3}$ & $36.18(-0.93)$ & $0.1129(0.8), 0.1129$ \\
& & $(0.8), 0.1130(0.9)$ \\
$\mathrm{CH}_{3} \mathrm{CHO} \cdots \mathrm{ClCF}_{3}$ (a) & $35.10(-2.01)$ & $0.1136(1.5), 0.1136$ \\
& & $(1.5), 0.1142(2.1)$ \\
$\mathrm{CH}_{3} \mathrm{CHO} \cdots \mathrm{ClCF}_{3}$ (b) & $35.26(-1.85)$ & $0.1134(1.3), 0.1138$ \\
& & $(1.7), 0.1142(2.1)$ \\
$\mathrm{CH}_{3} \mathrm{CFO} \cdots \mathrm{ClCF}_{3}$ (a) & $36.64(-1.47)$ & $0.1136(1.5), 0.1136$ \\
& & $(1.5), 0.1137(1.6)$ \\
$\mathrm{CH}_{3} \mathrm{CFO} \cdots \mathrm{ClCF}_{3}$ (b) & $35.66(-1.45)$ & $0.1133(1.2), 0.1129$ \\
& & $(0.8), 0.1139(1.8)$ \\
$\left(\mathrm{CH}_{3}\right)_{2} \mathrm{CO} \cdots \mathrm{ClCF}_{3}$ & $35.29(-1.82)$ & $0.1136(1.5), 0.1142$ \\
& & $(2.1), 0.1138(1.7)$ \\
\hline
\end{tabular}

$\sigma^{*}(\mathrm{C}-\mathrm{Cl})$ orbitals and the variation of the occupation of the $\sigma^{*}(\mathrm{C}-\mathrm{F})$ orbitals are indicated.

The results of Table 6 show that the charge transfer from the ketones to $\mathrm{CClF}_{3}$ is rather low, ranging from $0.5 \mathrm{me}$ $\left(\mathrm{F}_{2} \mathrm{CO}\right)$ to 4.9 me $\left(\mathrm{CH}_{3} \mathrm{CHO}\right)$. Let us notice that for the systems involving $\mathrm{H}_{2} \mathrm{CO}, \mathrm{F}_{2} \mathrm{CO}$ and $\mathrm{HFCO}$, there is also a CT from the LPs of the $\mathrm{O}$ atom to the Rydberg orbitals of the $\mathrm{Cl}$ atom. The corresponding second-order stabilization energies are comprised between $0.39 \mathrm{kcal} \mathrm{mol}^{-1}$ $\left(\mathrm{F}_{2} \mathrm{CO}\right)$ and $0.44 \mathrm{kcal} \mathrm{mol}^{-1}\left(\mathrm{H}_{2} \mathrm{CO}\right)$. It must be mentioned that these values are of the same order of magnitude as the $E^{2}\left(\mathrm{LPO} \rightarrow \sigma^{*}(\mathrm{C}-\mathrm{Cl})\right.$ stabilization energies which range between 0.3 and $0.58 \mathrm{kcal} \mathrm{mol}^{-1}$ (Table 7). This effect is rather unusual and illustrates the electrophilic feature of the halogen. For the other systems, the charge transfer energy to the Rydberg orbitals of $\mathrm{Cl}$ is smaller (between 0.07 and $0.18 \mathrm{kcal} \mathrm{mol}^{-1}$ ).

In a first step, we will discuss the origin of the variation of the $\mathrm{C}-\mathrm{Cl}$ and $\mathrm{C}-\mathrm{F}$ bond lengths. The interaction with ketones results in an increased polarization of the $\mathrm{C}-\mathrm{Cl}$ bond. The variations of the charges on the $\mathrm{C}$ and $\mathrm{Cl}$ atoms are +6.2 and -14.5 me for the weakest $\mathrm{F}_{2} \mathrm{CO}$ complex. The largest changes of the charges on the $\mathrm{C}$ atom $(+16.9 \mathrm{me})$ and on the $\mathrm{Cl}$ atom $(-31.6 \mathrm{me})$ are predicted for the $\left(\mathrm{CH}_{3}\right)_{2} \mathrm{CO} \cdots \mathrm{ClCF}_{3}$ system. For this system, the $\mathrm{CT}$ to the three $\mathrm{F}$ atoms is also the largest (19 me). Let us notice that for $\mathrm{CClF}_{3}$ complexed with stronger electron donors such as $\mathrm{Br}^{-}$, the $\mathrm{CT}$ is equal to $15.4 \mathrm{me}$ [24].

As indicated in Table 7, the second-order stabilization energies $E^{2} \rightarrow \sigma^{*}(\mathrm{C}-\mathrm{Cl})$ increase from $\mathrm{F}_{2} \mathrm{CO}$ $\left(0.3 \mathrm{kcal} \mathrm{mol}^{-1}\right)$ to $\mathrm{CH}_{3} \mathrm{CHO}\left(1.24 \mathrm{kcal} \mathrm{mol}^{-1}\right)$. Despite this charge transfer, the occupation of the $\sigma^{*}(\mathrm{C}-\mathrm{Cl})$ orbital decreases, its decrease being slightly larger for the $\left(\mathrm{CH}_{3}\right)_{2} \mathrm{CO}$ system $(12.7 \mathrm{me})$ than for the $\mathrm{F}_{2} \mathrm{CO}$ one (11.4 me). Our calculations also predict a small decrease of the $\sigma(\mathrm{C}-\mathrm{Cl})$ occupation between 0.7 and 1.1 me. Further, as indicated in Table 6, the interaction results in an increase of the s-character of the $\mathrm{C}(\mathrm{Cl})$ atom, smaller for the weaker complexes $\left(\mathrm{F}_{2} \mathrm{CO}=0.37 \%\right)$ than for the stronger ones $\left[\left(\mathrm{CH}_{3}\right)_{2} \mathrm{CO}=0.92 \%\right]$. It must be pointed out that a variation of hybridization of the $\mathrm{C}(\mathrm{Cl})$ atom of $\mathrm{CClF}_{3}$ is a known effect which has already been predicted for $\mathrm{CClF}_{3}$ complexed with molecules such as $\mathrm{NH}_{3}$ [24], $\mathrm{H}_{2} \mathrm{O}$ and $\mathrm{H}_{2} \mathrm{~S}$ [25].

Both the increase of the s-character of the $\mathrm{C}(\mathrm{Cl})$ atom and the decrease of the $\sigma^{*}(\mathrm{C}-\mathrm{Cl})$ occupation contribute to the contraction of the $\mathrm{C}-\mathrm{Cl}$ bond. The variation of the $\sigma(\mathrm{C}-$ $\mathrm{Cl}$ ) occupation is very small, but it has been considered in our calculations. From the present results, we have deduced the following dual expression $\left[\Delta \mathrm{r}(\mathrm{C}-\mathrm{Cl})\right.$ in $\mathrm{m} \AA, \Delta \sigma^{*}(\mathrm{C}-$ $\mathrm{Cl}$ ) in me]:

$$
\begin{aligned}
\Delta r(\mathrm{C}-\mathrm{Cl})= & -8.07[\Delta \% s \mathrm{C}(\mathrm{Cl})] \\
& +0.16[\Delta \sigma *(\mathrm{C}-\mathrm{Cl})+\Delta \sigma(\mathrm{C}-\mathrm{Cl})]
\end{aligned}
$$




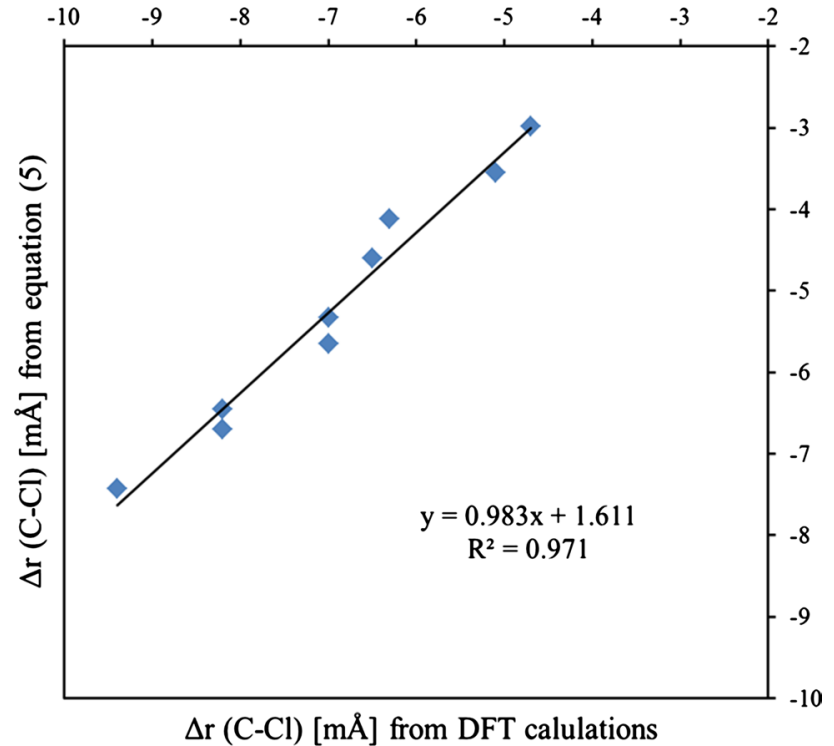

Fig. $4 \Delta \mathrm{r}(\mathrm{Cl}-\mathrm{Cl})(\mathrm{m} \AA)$ calculated by Eq. (5) as a function of $\Delta \mathrm{r}$ $(\mathrm{Cl}-\mathrm{Cl})$ calculated at the B3LYP/6-311++G(d,p) level

which illustrates the predominance of the hybridization effect over the $\sigma^{*}(\mathrm{C}-\mathrm{Cl})$ and $\sigma(\mathrm{C}-\mathrm{Cl})$ occupations. The values of $\Delta \mathrm{r}(\mathrm{C}-\mathrm{Cl})$ calculated by Eq. (5) and by the B3LYP method are compared in Fig. $4\left(r^{2}=0.971\right)$.

In order to test the validity of this equation, we have calculated the $\Delta \mathrm{r}(\mathrm{C}-\mathrm{Cl})$ value for the $\mathrm{F}_{3} \mathrm{CCl} \cdots \mathrm{Br}^{-}$system from the parameters reported in Ref. [24]. This complex is strong, the interaction energy calculated by MP2(full)/6$311++\mathrm{G}(\mathrm{d}, \mathrm{p})$ being $-7.27 \mathrm{kcal} \mathrm{mol}^{-1}$. The parameters of Eq. (5) are: $\Delta \% s(\mathrm{C}-\mathrm{Cl})=+2.68, \Delta \sigma^{*}(\mathrm{C}-\mathrm{Cl})=-4.1 \mathrm{me}$, $\Delta \sigma(\mathrm{C}-\mathrm{Cl})=+1.2 \mathrm{me}$. Note that in contrast to the present systems, there is an increase of the $\sigma(\mathrm{C}-\mathrm{Cl})$ occupation. From these parameters, a $\Delta \mathrm{r}(\mathrm{C}-\mathrm{Cl})$ value of $-22.5 \mathrm{~m} \AA$ has been calculated from Eq. (5) which is very close to the value of $-22.1 \mathrm{~m} \AA$ predicted by MP2 calculation in Ref. [24].

In a similar way, the elongation of the $\mathrm{C}-\mathrm{F}$ bond can be evaluated from the same parameters, the variation of the occupation of the $\sigma(\mathrm{C}-\mathrm{F})$ orbitals being negligible:

$\Delta r(\mathrm{C}-\mathrm{F})=-14.14[\Delta \% s \mathrm{C}(\mathrm{F})]+0.24 \Delta \sigma *(\mathrm{C}-\mathrm{F})$

Our calculations predict an increase of the polarity of the $\mathrm{C}-\mathrm{Cl}$ bond along with an increase of the s-character of the $\mathrm{C}(\mathrm{Cl})$ atom. These results are in agreement with the Bent's rule. Let us briefly remember that the Bent's rule states that atoms maximize their s-character in hybrid orbitals aimed toward electropositive substituents and the atoms maximize their p-character toward electronegative substituents. This rule has been discussed in detail for systems involving $\mathrm{CClF}_{3}$ complexed with Lewis acids and Lewis bases [28]. Let us notice that in the present systems, an increase of the s-character is also reflected in the variation of the intramolecular angle in $\mathrm{CClF}_{3}$. Indeed, in isolated $\mathrm{CClF}_{3}$, the $\mathrm{CClF}$ and FCF angles are equal to $110.3^{\circ}$ and $108.6^{\circ}$; in the complex with $\left(\mathrm{CH}_{3}\right)_{2} \mathrm{CO}$, these angles take values of $110.8^{\circ}$ and $108.1^{\circ}$.

For the present systems, the correlation between the charges on the $\mathrm{Cl}$ atom and the \% s-character in $\mathrm{C}$ orbital of the $\mathrm{C}-\mathrm{Cl}$ bond can be written as:

$q(\mathrm{Cl})(\mathrm{me})=0.035\left[(\% s \mathrm{C}(\mathrm{Cl})]-0.908 \quad\left(r^{2}=0.989\right)\right.$

Interestingly, for $\mathrm{CClF}_{3}$ complexed with stronger electron donors $\left(\mathrm{OH}^{-}, \mathrm{Cl}^{-}\right)$, we have found a very similar correlation ${ }^{1}$ from the data reported in Ref. [28].

Let us now discuss more in detail the changes occurring in the $\mathrm{C}-\mathrm{F}$ bonds of $\mathrm{CClF}_{3}$. The interaction with ketones results in a decrease of the $s$-character in $\mathrm{C}$ orbital of the $\mathrm{C}-\mathrm{F}$ bond (in order to preserve the total $s$-character of the $\mathrm{C}$ atom). Further, as indicated in Table 6, the interaction with ketones results in an increase of the charges on the external $\mathrm{F}$ atoms. The sum of these charges increases is larger than the variation of charges on the $\mathrm{C}$ atoms, being, for example, 8.9 me for the $\mathrm{F}_{2} \mathrm{CO}$ system and 19.4 me for the $\left(\mathrm{CH}_{3}\right)_{2} \mathrm{CO}$ system. These variations can be explained by the fact that in isolated $\mathrm{CClF}_{3}$ there is a strong intramolecular delocalization, taking place from one of the LP of the $\mathrm{F}$ atoms to the $\sigma^{*}(\mathrm{C}-\mathrm{Cl})$ orbital. For each of the $\mathrm{F}$ atoms, this delocalization is equal to $12.37 \mathrm{kcal} \mathrm{mol}^{-1}$, giving a sum of $37.11 \mathrm{kcal} \mathrm{mol}^{-1}$ in the isolated molecule. Complex formation results in a decrease of this delocalization, in the range between $0.93 \mathrm{kcal} \mathrm{mol}^{-1}\left(\mathrm{~F}_{2} \mathrm{CO}\right)$ and $2.01 \mathrm{kcal} \mathrm{mol}^{-1}$ $\left(\mathrm{CH}_{3} \mathrm{CHO}\right)$. It must be also mentioned that in isolated $\mathrm{CClF}_{3}$, there are other intramolecular delocalizations which are not very sensitive to complex formation. This is the case of the energy of the LPF1 $\rightarrow \sigma^{*}\left(\mathrm{CF}_{2}\right)$ delocalization equal to $30.30 \mathrm{kcal} \mathrm{mol}^{-1}$ in the isolated molecule and decreasing by only $0.39 \mathrm{kcal} \mathrm{mol}^{-1}$ in the $\mathrm{CH}_{3} \mathrm{CHO}$ complex. Further, the weak delocalization from $\sigma(\mathrm{C}-\mathrm{Cl})$ to $\sigma^{*}(\mathrm{C}-\mathrm{Cl})$ decreases by ca $0.15 \mathrm{kcal} \mathrm{mol}^{-1}$ by complex formation. These delocalizations will no more be considered hereafter.

Let us mention that a nice effect of electron transfer from the LPs of the halogen atoms to the remote part of the complex has been predicted in the $\mathrm{H}_{3} \mathrm{~N}-\mathrm{CCl}_{4}$ system characterized by the $\mathrm{N} \cdots \mathrm{ClCCl}_{3}$ interaction. In this system, the three LPs of the bonded $\mathrm{Cl}$ atom are delocalized to the three external $\mathrm{C}-\mathrm{Cl}$ bonds, resulting in an increase of the $\sigma^{*}(\mathrm{C}-$ $\mathrm{Cl}$ ) occupation in these three external bonds and a contraction of the $\mathrm{C}-\mathrm{Cl}$ bond involved in the interaction [64].

\footnotetext{
1 The correlation computed from the data of Ref. [28] can be written $q(\mathrm{Cl})(\mathrm{me})=0.032(\% s$-character C $)-0.0926\left(r^{2}=0.993\right)$.
} 
Fig. 5 The donor-acceptor orbitals involved in the two-step mechanism: first step, $\mathrm{LP} 1 \mathrm{O} \rightarrow \sigma^{*}(\mathrm{C}-\mathrm{Cl})$ and $\mathrm{LP} 2 \mathrm{O} \rightarrow \sigma^{*}(\mathrm{C}-\mathrm{Cl})$; second step, $\mathrm{LP}(\mathrm{F}) \rightarrow \sigma^{*}(\mathrm{C}-\mathrm{Cl})$ interaction

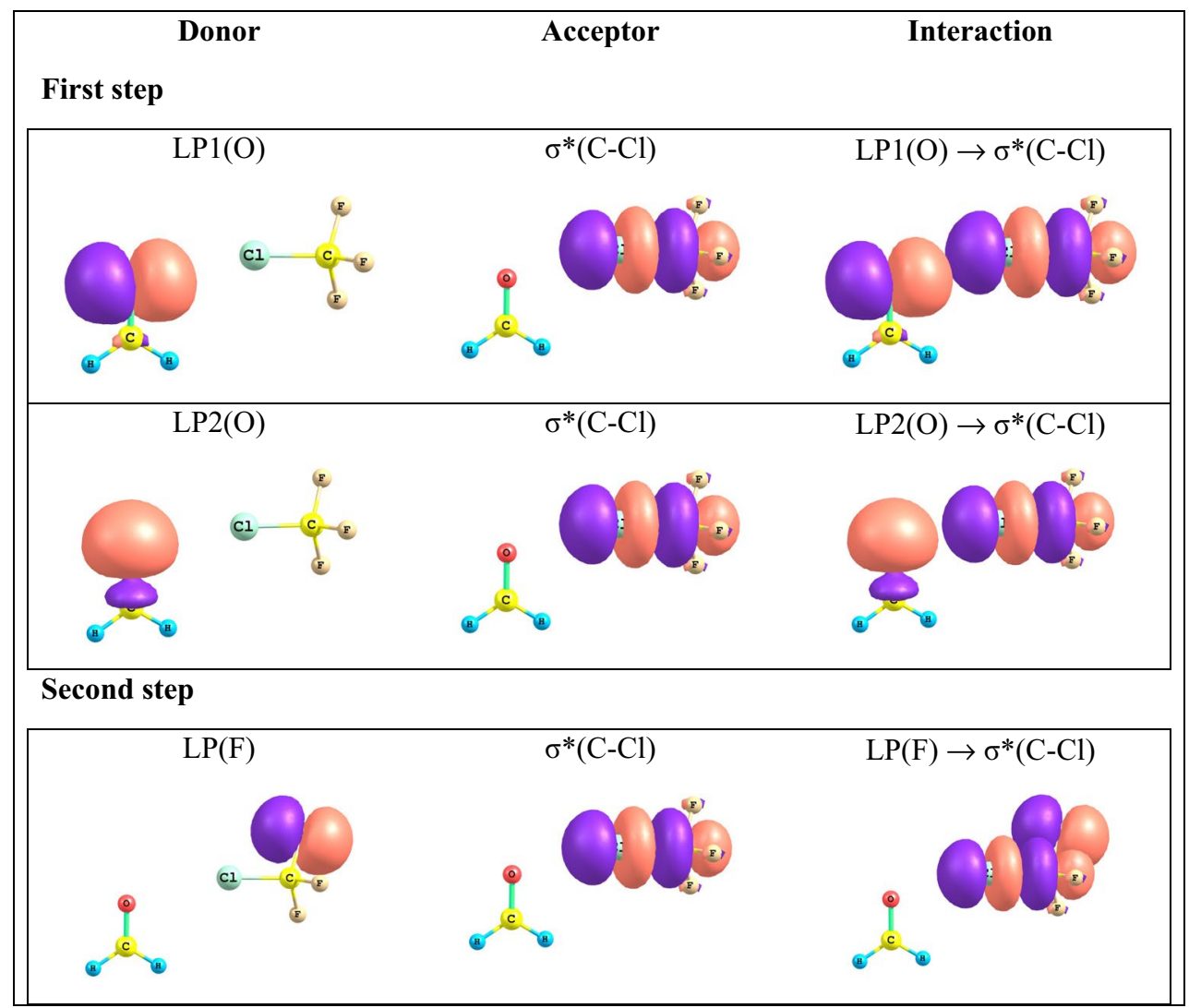

It follows from these considerations that the formation of the present complexes can be considered as originating from a two-step mechanism: the intermolecular charge transfer from the $\mathrm{LPsO}$ to $\sigma^{*}(\mathrm{C}-\mathrm{Cl})$ followed by a decrease of the intramolecular charge transfer from LPF to $\sigma^{*}(\mathrm{C}-$ $\mathrm{Cl})$. Both effects are connected as illustrated by the following correlation:

$$
\begin{aligned}
& E^{2}(\mathrm{LPsO} \rightarrow \sigma * \mathrm{C}-\mathrm{Cl}) \\
& \quad=-0.82\left[\Delta E^{2}(\mathrm{LP} \mathrm{F} \rightarrow \sigma *(\mathrm{C}-\mathrm{Cl})]-0.45 \quad\left(r^{2}=0.954\right)\right.
\end{aligned}
$$

showing the predominance of the intramolecular effect over the intermolecular one. Figure 5 illustrates selected orbitals involved in the above-mentioned two-step mechanism. It must be mentioned that a similar effect has been demonstrated for the $\mathrm{CHF}_{3}$ molecule hydrogen-bonded to proton acceptor of medium strength [75]. In the isolated $\mathrm{CHF}_{3}$ molecule, the intramolecular hyperconjugation energy occurring from the three $\mathrm{F}$ atoms to the $\sigma^{*}(\mathrm{CH})$ bond is equal to $26.40 \mathrm{kcal} \mathrm{mol}^{-1}$. This value is similar to the hyperconjugation energy from the three $\mathrm{F}$ atoms to $\sigma^{*}(\mathrm{C}-\mathrm{Cl})$ deduced in the present work for isolated $\mathrm{CClF}_{3}$. In the $\mathrm{F}_{3} \mathrm{CH} \cdots \mathrm{OH}_{2}$ complex, this hyperconjugation energy decreases by $3.8 \mathrm{kcal} \mathrm{mol}^{-1}$ and predominates over the intermolecular effect. As a consequence, the $\mathrm{C}-\mathrm{H}$ bond is contracted by a small amount. It should be noted that the interaction between $\mathrm{CHF}_{3}$ and stronger proton acceptors
Table 9 SAPT (MP2/cc-pVTZ) interaction energies ( $E_{\text {int }}$,

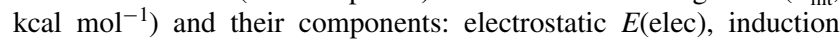
$E$ (ind), dispersion $E$ (disp) and exchange $E$ (exch) for the complexes investigated

\begin{tabular}{llllll}
\hline System & $E_{\text {int }}$ & $E($ elec $)$ & $E($ ind $)$ & $E($ disp $)$ & $E($ exch $)$ \\
\hline $\mathrm{H}_{2} \mathrm{CO} \cdots \mathrm{ClCF}_{3}$ & -1.77 & -2.41 & -0.28 & -1.33 & 2.25 \\
$\mathrm{HFCO} \cdots \mathrm{C}_{1 C F}(\mathrm{a})$ & -1.32 & -1.56 & -0.16 & -0.87 & 1.26 \\
$\mathrm{HFCO} \cdots \mathrm{C} 1 \mathrm{CF}_{3}(\mathrm{~b})$ & -1.41 & -1.54 & -0.18 & -0.84 & 1.16 \\
$\mathrm{~F}_{2} \mathrm{CO} \cdots \mathrm{C} 1 \mathrm{CF}_{3}$ & -1.13 & -1.14 & -0.12 & -0.76 & 0.89 \\
$\mathrm{CH}_{3} \mathrm{CHO} \cdots \mathrm{ClCF}_{3}(\mathrm{a})$ & -2.08 & -2.81 & -0.36 & -1.49 & 2.58 \\
$\mathrm{CH}_{3} \mathrm{CHO} \cdots \mathrm{ClCF}_{3}(\mathrm{~b})$ & -2.11 & -2.66 & -0.36 & -1.40 & 2.31 \\
$\mathrm{CH}_{3} \mathrm{CFO} \cdots \mathrm{ClCF}_{3}(\mathrm{a})$ & -1.70 & -1.91 & -0.25 & -1.00 & 1.46 \\
$\mathrm{CH}_{3} \mathrm{CFO} \cdots \mathrm{CICF}_{3}(\mathrm{~b})$ & -1.73 & -2.08 & -0.25 & -1.36 & 1.95 \\
$\left(\mathrm{CH}_{3}\right)_{2} \mathrm{CO} \cdots \mathrm{ClCF}_{3}$ & -2.32 & -3.41 & -0.50 & -1.80 & 3.39 \\
\hline
\end{tabular}

such as $\mathrm{F}^{-}$or $\mathrm{Cl}^{-}$results in a net increase of the $\sigma^{*}(\mathrm{C}-\mathrm{H})$ occupation, a decrease of the $\sigma^{*}(\mathrm{C}-\mathrm{F})$ occupation and an elongation of the $\mathrm{C}-\mathrm{H}$ bond. This is in strong contrast to the halogen bonds, the interaction between $\mathrm{CClF}_{3}$ and $\mathrm{Br}^{-}$ or $\mathrm{OH}^{-}$resulting in a contraction of the $\mathrm{C}-\mathrm{Cl}$ bond, as previously mentioned.

As for $\mathrm{CClF}_{3}, \mathrm{CBrF}_{3}, \mathrm{CBrCl}_{3}$ complexed with $\mathrm{F}^{-}, \mathrm{Cl}^{-}$ and $\mathrm{Br}^{-}$[30], in the present systems there is also a correlation between the binding energies and the second-order interaction energies $E^{2} \mathrm{LPsO} \rightarrow \sigma^{*}(\mathrm{C}-\mathrm{Cl})$. The best fit is found for the following logarithmic equation: 
Table $10 v(\mathrm{C}-\mathrm{Cl})$ and $v(\mathrm{C}-\mathrm{F})$ frequencies $\left(\mathrm{cm}^{-1}\right)$ in isolated and complexed $\mathrm{CClF}_{3}$

\begin{tabular}{lllll}
\hline & Isolated & $\mathrm{F}_{2} \mathrm{C}=\mathrm{O}$ & $\mathrm{HFC}=\mathrm{O}(\mathrm{a})$ & $\mathrm{HFC}=\mathrm{O}(\mathrm{b})$ \\
\hline$v(\mathrm{C}-\mathrm{Cl})\left(\mathrm{A}_{1}\right)$ & 1073.5 & $1077.8(+4.3)$ & $1079.6(+6.3)$ & $1081.1(+6.6)$ \\
$\nu(\mathrm{C}-\mathrm{F})(\mathrm{E})$ & 1181.3 & $1173.5(-7.8)$ & $1170.9(-10.4)$ & $1170.9(-10.4)$ \\
& & & $1173.9(-7.4)$ & $1171.2(-10.1)$ \\
& $\mathrm{CH}_{3} \mathrm{CFO}(\mathrm{a})$ & $\mathrm{CH}_{3} \mathrm{CFO}(\mathrm{b})$ & $\mathrm{H}_{2} \mathrm{CO}$ & $\mathrm{CH}_{3} \mathrm{CHO}(\mathrm{a})$ \\
$\nu(\mathrm{C}-\mathrm{Cl})\left(\mathrm{A}_{1}\right)$ & $1080.7(+7.2)$ & $1079.8(+6.3)$ & $1081.1(+7.6)$ & $1082.2(+8.7)$ \\
$v(\mathrm{C}-\mathrm{F})(\mathrm{E})$ & $1167.9(-13.4)$ & $1168.1(-13.2)$ & $1166.7(-14.6)$ & $1163.9(-13.4)$ \\
& $1168.3(-13.0)$ & $1172.1(-9.2)$ & $1169.5(-11.8)$ & $1166.7(-14.6)$ \\
& $\mathrm{CH}_{3} \mathrm{CHO}(\mathrm{b})$ & $\mathrm{CH}_{3} \mathrm{COCH}$ & & \\
$v(\mathrm{C}-\mathrm{Cl})\left(\mathrm{A}_{1}\right)$ & $1081.7(+8.2)$ & $1083.0(+9.5)$ & & \\
$v(\mathrm{C}-\mathrm{F})(\mathrm{E})$ & $1163.9(-17.4)$ & $1162.0(-19.3)$ & & \\
& $1167.8(-13.5)$ & $1165.0(-15.1)$ & & \\
\hline
\end{tabular}

$$
\begin{aligned}
-\Delta E= & 0.985 \ln \left[E^{2} \mathrm{LPsO} \rightarrow \sigma *(\mathrm{C}-\mathrm{Cl})\right] \\
& +2.27 \quad\left(r^{2}=0.941\right)
\end{aligned}
$$

It should be mentioned that a unique correlation between the $-\Delta \mathrm{E}$ and $E^{2}$ values was proposed in Ref. [30] for the different systems. The lower correlation coefficient of 0.819 probably results from the fact that each system is characterized by another correlation depending on the specific features of the halomethanes. This shows the advantage to consider closely related systems.

\subsection{SAPT decomposition of the energies}

To evaluate the physically meaningful components of the interaction energy in the complexes studied, a SAPT analysis has been performed at the MP2/cc-pVTZ level of theory. The results are collected in Table 9. The SAPT interaction energies vary between -1.13 and $-2.32 \mathrm{kcal} \mathrm{mol}^{-1}$ for the complexes investigated. As follows from these results, the electrostatic term $E$ (elec) is the dominant attraction component representing about $60 \%$ of the total attraction forces. With regard to the induction $E$ (ind) and dispersion $E$ (disp) components, they account for about 10 and $30 \%$ of the total attraction forces, respectively. The value of the repulsive exchange energy $E$ (exch) is lower than the absolute value of the electrostatic term $E$ (elec). Similar results have been found for the halogen bonded complexes between carbonyl bases and molecular chlorine calculated at the same level of theory [52].

\subsection{Frequencies of the $v(\mathrm{C}-\mathrm{Cl})$ and $v(\mathrm{C}-\mathrm{F})$ vibrations}

The calculated frequencies of the $v(\mathrm{C}-\mathrm{Cl})$ and $v(\mathrm{C}-\mathrm{F})$ vibrations in isolated and complexed $\mathrm{CClF}_{3}$ are indicated in Table 10. For isolated $\mathrm{CClF}_{3}$ the $v(\mathrm{C}-\mathrm{Cl})$ stretching vibration is predicted at $1073.5 \mathrm{~cm}^{-1}$ in good agreement with the value reported in Ref. [30]. The $v(\mathrm{C}-\mathrm{F})$ vibration is predicted at $1181.3 \mathrm{~cm}^{-1}$. These values are in good agreement with the respective values of 1099.4 and $1208.0 \mathrm{~cm}^{-1}$ observed in liquid argon at $89 \mathrm{~K}$ [19]. The interaction with ketones results in an increase of the $v(\mathrm{C}-\mathrm{Cl})$ frequency from $4.3 \mathrm{~cm}^{-1}\left(\mathrm{~F}_{2} \mathrm{CO}\right)$ to $9.5 \mathrm{~cm}^{-1}\left[\left(\mathrm{CH}_{3}\right)_{2} \mathrm{CO}\right]$. The degenerate $v(\mathrm{C}-\mathrm{F})$ vibrations are split into two components, and their frequencies decrease from 7.8 to $19.3 \mathrm{~cm}^{-1}$.

As demonstrated in numerous hydrogen-bonded systems, the interaction energies and the frequency shifts of the stretching vibration of the bond involved in the interaction are linearly related. This correlation was originally referred as the Badger-Bauer correlation [76, 77].

For the present systems, there is only a very crude correlation between the interaction energies and the frequency shifts:

$-\Delta E=0.333 \Delta v(\mathrm{C}-\mathrm{Cl})-0.40 \quad\left(r^{2}=0.862\right)$

This can be accounted for by the fact that the interaction energies are extended to the whole $\mathrm{F}_{3} \mathrm{CCl}$ molecule and that the $v(\mathrm{C}-\mathrm{Cl})$ stretching vibration is a more localized mode.

\section{Conclusions}

In this work, the halogen bonded complexes of six carbonyl bases: $\mathrm{H}_{2} \mathrm{C}=\mathrm{O} ; \quad \mathrm{HFC}=\mathrm{O} ; \mathrm{F}_{2} \mathrm{C}=\mathrm{O} ; \mathrm{CH}_{3} \mathrm{HC}=\mathrm{O}$; $\mathrm{CH}_{3} \mathrm{FC}=\mathrm{O} ; \quad\left(\mathrm{CH}_{3}\right)_{2} \mathrm{C}=\mathrm{O}$ with chlorotrifluoromethane have been studied using ab initio MP2 and $\operatorname{CCSD}(\mathrm{T})$ as well as density functional theory (B3LYP, B3LYP-D3 and wB97XD) methods. The most important conclusions are the following:

1. In these complexes, the intermolecular $\mathrm{O} \cdots \mathrm{Cl}$ distances are all smaller than the sum of the van der Waals radii. 
2. The interaction energies calculated at the $\operatorname{CCSD}(\mathrm{T}) /$ aug-cc-pVTZ level vary between -1.22 and $-2.62 \mathrm{kcal} \mathrm{mol}^{-1}$. The largest $\Delta E^{\mathrm{CCSD}(\mathrm{T})}$ is predicted for the $\left(\mathrm{CH}_{3}\right)_{2} \mathrm{CO} \cdots \mathrm{ClCF}_{3}$ system, while the smallest interaction energy has been obtained for the $\mathrm{F}_{2} \mathrm{CO} \cdots \mathrm{ClCF}_{3}$ complex.

3. The B3LYP-D3 calculated interaction energies are linearly related to the ionization potential and the proton affinity of the carbonyl bases.

4. The interaction results in a contraction of the $\mathrm{C}-\mathrm{Cl}$ bond and an elongation of the $\mathrm{C}-\mathrm{F}$ bond. The variation of the bond lengths is accompanied by a blueshift of the $\mathrm{C}-\mathrm{Cl}$ stretching vibration and a redshift of the $\mathrm{C}-\mathrm{F}$ stretching vibration.

5. The NBO analysis shows that the increase of the $s$-character of the $\mathrm{C}(\mathrm{Cl})$ atom largely predominates over the decrease of the $\sigma^{*}(\mathrm{C}-\mathrm{Cl})$ occupation in determining the contraction of the $\mathrm{C}-\mathrm{Cl}$ bond.

6. The elongation of the $\mathrm{C}-\mathrm{F}$ bonds is explained by a decrease of intramolecular delocalization from one of the lone-pair orbital (LP) of the F atoms to the $\sigma^{*}(\mathrm{C}-$ $\mathrm{Cl}$ ) orbital.

7. It is suggested that the formation of these complexes originates from a two-step mechanism: the intermolecular charge transfer from the lone-pair orbitals of the $\mathrm{O}$ atom $(\mathrm{LPsO})$ to the $\sigma^{*}(\mathrm{C}-\mathrm{Cl})$ antibonding orbital followed by a decrease of the intramolecular charge transfer from the $\mathrm{LP}$ on the fluorine atom to the $\sigma^{*}(\mathrm{C}-\mathrm{Cl})$ orbital.

8. The SAPT results for these complexes show that the dispersion and electrostatic contributions cover about $90 \%$ of the total attraction forces. The exchange energy $E$ (exch) is lower than the absolute value of the electrostatic term $E$ (elec). Similar results were found in the case of the carbonyl bases complexed with molecular chlorine [38].

Acknowledgments This work was financed in part by a statutory activity subsidy from the Polish Ministry of Science and Higher Education for the Faculty of Chemistry of Wroclaw University of Technology. A generous computer time from the Wroclaw Supercomputer and Networking Center as well as the Poznan Supercomputer and Networking Center is acknowledged. Th. Z. H thanks the University of Leuven for computer facilities.

Open Access This article is distributed under the terms of the Creative Commons Attribution 4.0 International License (http://creativecommons.org/licenses/by/4.0/), which permits unrestricted use, distribution, and reproduction in any medium, provided you give appropriate credit to the original author(s) and the source, provide a link to the Creative Commons license, and indicate if changes were made.

\section{References}

1. Pimentel GC, McClellan AL (1960) The hydrogen bond. W.H. Freeman Co., San Francisco, London
2. Mulliken RS, Person WB (1969) Molecular complexes. A lecture and reprint volume. Wiley-Interscience. Wiley, New York

3. Metrangolo P, Resnati G (2001) Halogen bonding: a paradigm in supramolecular chemistry. Chem Eur J 7:2511-2519

4. Chu QL, Wang ZM, Huang QC, Yan CH, Zhu SZ (2001) Fluorine-containing donor-acceptor complexes: infinite chains formed by oxygen $\cdots$ iodine interactions. J Am Chem Soc 123:11069-11070

5. Nguyen HL, Horton PN, Hursthouse MB, Legon AC, Bruce DW (2004) Halogen bonding: a new interaction for liquid crystal formation. J Am Chem Soc 126:16-17

6. Wang W, Zhang Y, Ji B, Tian A (2011) On the correlation between bond-length change and vibrational frequency shift in halogen-bonded complexes. J Chem Phys 134:224303

7. Riley KE, Merz KM (2007) Insights into the strength and origin of halogen bonding: the halobenzene-formaldehyde dimer. $\mathbf{J}$ Phys Chem A 111:1688-1694

8. Amezaga NJM, Pamies SC, Peruchena NN, Sosa GL (2010) Halogen bonding: a study based on the electronic charge density. J Phys Chem A 114:552-562

9. Donald KJ, Wittmaack BK, Crigger C (2010) Tuning $\sigma$-holes: charge redistribution in the heavy (group 14) analogues of simple and mixed halomethanes can impose strong propensities for halogen bonding. J Phys Chem A 114:7213-7222

10. Wang W (2011) Halogen bond involving hypervalent halogen: CSD search and theoretical study. J Phys Chem A 115:9294-9299

11. Legon AC (2010) The halogen bond: an interim perspective. Phys Chem Chem Phys 12:7736-7747

12. Zhang X, Zeng Y, Li X, Meng L, Zheng S (2011) A computational study on the nature of the halogen bond between sulfides and dihalogen molecules. Struct Chem 22:567-576

13. Hill JG, Legon A (2015) On the directionality and non-linearity of halogen and hydrogen bonds. J Phys Chem Chem Phys 17:858-867

14. Otero-de-la-Roza A, Johnson ER, DiLabio GA (2014) Halogen bonding from dispersion-corrected density-functional theory: the role of delocalization error. J Chem Theor Comput 10:5436-5447

15. Azofra LM, Scheiner S (2014) Substituent effects in the noncovalent bonding of $\mathrm{SO}_{2}$ to molecules containing a carbonyl group. The dominating role of the chalcogen bond. J Phys Chem A 21:3835-3845

16. Kozuch S, Martin JML (2013) Halogen bonds: benchmarks and theoretical analysis. J Chem Theory Comput 9:1918-1931

17. Alkorta I, Elguero J (2014) Characterizing traditional and chlorine-shared halogen bonds in complexes of phosphine derivatives with $\mathrm{ClF}$ and $\mathrm{Cl}_{2}$. J Phys Chem A 118(23):4222-4231

18. Scheiner S (2015) The interplay between charge transfer, rehybridization, and atomic charges in the internal geometry of subunits in noncovalent interactions. Int J Quant Chem 115:28-33

19. Stone AJ (2013) Are halogen bonded structures electrostatically driven? J Am Chem Soc 135:7005-7009

20. Sutradhar D, Chandra AK, Zeegers-Huyskens Th (2014) A theoretical investigation of the interaction between fluorinated dimethyl ethers and molecular chlorine. Mol Phys 112:2791-2801

21. Zou J-W, Jiang Y-J, Guo M, Hu G-X, Zhang B, Liu H-C, Yu Q-S (2005) Ab initio study of the complexes of halogen-containing molecules $\mathrm{RX}(\mathrm{X}=\mathrm{Cl}, \mathrm{Br}$, and $\mathrm{I})$ and $\mathrm{NH}_{3}$ : towards understanding the nature of halogen bonding and the electron-accepting propensities of covalently bonded halogen atoms. Chem Eur J $11: 740-751$

22. Jahromi WJ, Eskandari K (2013) Halogen bonding: a theoretical study based on atomic multipoles derived from quantum theory of atoms in molecules. Struct Chem 24:1281-1287

23. Wang W, Wang N-B, Zheng W, Tian A (2004) Theoretical study on the blueshifting halogen bond. J Phys Chem A 108:1799-1805 
24. Wang W, Hobza P (2008) Origin of the $\mathrm{X}-\mathrm{Hal}(\mathrm{Hal}=\mathrm{Cl}, \mathrm{Br})$ bond-length change in the halogen-bonded complexes. J Phys Chem A 112:4114-4119

25. Zhao Q, Feng D, Hao J, Cai Z (2010) Chemical origin of contracted $\mathrm{C}-\mathrm{Cl}$ bonds in the halogen-bonded complexes. J Mol Struct (THEOCHEM) 958:71-75

26. Tawfik M, Donald K (2014) Halogen bonding: unifying perspectives on organic and inorganic cases. J Phys Chem A 118:10090-10100

27. Grabowski SJ (2012) QTAIM characteristics of halogen bond and related interactions. J Phys Chem A 116:1838-1845

28. Grabowski SJ (2011) Halogen bond and its counterparts: Bent's rule explains the formation of nonbonding interactions. J Phys Chem A 115:12340-12347

29. Grabowski SJ (2013) Non-covalent interactions-QTAIM and NBO analysis. J Mol Model 19:4713-4721

30. Zhang Y, Li A-Y, Cao L-J (2012) Electronic properties of the halogen bonds $\mathrm{Z}{ }_{3} \mathrm{CX} \cdots \mathrm{Y}^{-}$between halide anions and methyl halides. Struct Chem 23:627-636

31. Scheiner S (2013) Detailed comparison of the pnicogen bond with chalcogen, halogen, and hydrogen bonds. Int J Quant Chem 113:1609-1620

32. Hauchecorne D, Szostak R, Herrebout WA, van der Veken B (2009) C-X ‥O halogen bonding:interactions of trifluoromethyl halides with dimethyl ether. J Chem Phys Chem 10:2105-2115

33. Evangelisti L, Feng G, Gou Q, Grabov J-U, Caminati W (2014) Halogen bond and free internal rotation: the microwave spectrum of $\mathrm{CF}_{3} \mathrm{Cl}$-dimethyl ether. $\mathrm{J}$ Phys Chem A 118:579-582

34. Clark T., Hennemann M., Murray J. S., Politzer P. (2007) Halogen bonding: the sigma-hole. In: Proceedings of modeling interactions in biomolecules II, Prague, 5-9 Sept 2005. J Mol Mod 13:291-296

35. Politzer P, Murray JS, Clark T (2013) Halogen bonding and other $\sigma$-hole interactions: a perspective. Phys Chem Chem Phys 15:11178-11189

36. Riley KE, Hobza P (2008) Investigations into the nature of halogen bonding including symmetry adapted perturbation theory analyses. J Chem Theory Comput 4:232-242

37. Gall J-F, Maria P-C (1990) In progress in physical organic chemistry. In: Taft RW (ed) vol 17. Wiley, New York/Chichester/Brisbane, pp 159-238

38. Møller C, Plesset MS (1934) Note on an approximation treatment for many-electron systems. Phys Rev 46:618-622

39. Kendall RA, Dunning TH Jr, Harrison RJ (1992) Electron affinities of the first-row atoms revisited. Systematic basis sets and wave functions. J Chem Phys 96:6796-6806

40. Becke AD (1993) Density-functional thermochemistry. III. The role of exact exchange. J Chem Phys 98:5648-5652

41. Lee C, Yang W, Parr RG (1988) Development of the Colle-Salvetti correlation-energy formula into a functional of the electron density. Phys Rev B 37:785-789

42. Grimme S, Antony J, Ehrlich S, Krieg H (2010) A consistent and accurate ab initio parametrization of density functional dispersion correction (DFT-D) for the 94 elements H-Pu. J Chem Phys $132: 154104$

43. Chai J-D, Head-Gordon M (2008) Long-range corrected hybrid density functionals with damped atom-atom dispersion corrections. Phys Chem Chem Phys 10:6615-6620

44. Krishnan R, Binkley JS, Seeger R, Pople JA (1980) Self-consistent molecular orbital methods. XX. A basis set for correlated wave functions. J Chem Phys 72:650-654

45. Frisch MJ, Pople AJ, Binkley JS (1984) Self-consistent molecular orbital methods 25. Supplementary functions for Gaussian basis sets. J Chem Phys 80:3265-3269
46. Boys SF, Bernardi F (1970) The calculation of small molecular interactions by the differences of separate total energies. Some procedures with reduced errors. Mol Phys 19:553-566

47. Frisch MJ, Trucks GW, Schlegel HB, Scuseria GE, Robb MA, Cheeseman JR, Scalmani G, Barone V, Mennucci B, Petersson et al (2009) Gaussian 09. Gaussian Inc, Wallingford

48. Werner HJ, Knowles PJ, Knizia G, Manby FR, Schütz M, Celani P, Korona T, Lindh R, Mitrushenkov A, Rauhut G et al (2012) MOLPRO, version 2012.1, a package of ab initio programs

49. Reed AE, Curtiss LA, Weinhold F (1988) Intermolecular interactions from a natural bond orbital, donor-acceptor viewpoint. Chem Rev 88:899-926

50. Glendening ED, Badenhoop JK, Reed AE, Carpenter JE, Bohmann JA, Morales CM, Weinhold F (2001) NBO 5.0 Software. Theoretical Chemistry Institute, University of Wisconsin, Madison. http://www.chem.wisc.edu/ nbo5

51. Todd A, Keith TK (2014) AIMAll (Version 14.11.23). Gristmill Software, Overland Park KS, USA, 2014 (aim.tkgristmill.com)

52. Zierkiewicz W, Bieńko DC, Michalska D, Zeegers-Huyskens Th (2015) Theoretical investigation of the halogen bonded complexes between carbonyl bases and molecular chlorine. J Comput Chem 36:821-832

53. Wiberg KB, Marquez M, Castejon H (1994) Lone pairs in carbonyl compounds and ethers. J Org Chem 59:6817-6822

54. Koch U, Popelier PLA (1995) Characterization of C-H-O hydrogen bonds on the basis of the charge density. J Phys Chem 99:9747

55. Popelier PLA (1998) Characterization of a dihydrogen bond on the basis of the electron density. J Phys Chem A 102:1873

56. Chandra AK, Zeegers-Huyskens Th (2012) A theoretical investigation of the interaction between substituted carbonyl derivatives and water: Open or cyclic complexes? J Comput Chem 33:1131-1141

57. Niu B, Shirley DA, Bai Y (1993) High resolution photoelectron spectroscopy and femtosecond intramolecular dynamics of $\mathrm{H}_{2} \mathrm{CO}^{+}$and $\mathrm{D}_{2} \mathrm{CO}^{+}$. J Chem Phys 98:4377-4390

58. Wittel K (1976) The photoelectron spectrum of formylfluoride. J Electron Spectrosc Relat Phenom 8:245-248

59. Buckley TJ, Johnson RD, Huie RE, Zhang Z, Kuo SC, Klemm RB (1995) Ionization Energies, appearance energies, and thermochemistry of CF2O and FCO. J Phys Chem 99:4879-4885

60. Hernandez R, Mouvier G (1977) Spectroscopie de photoelectrons d'aldehydes et de cetones aliphatiques. J Electron Spectrosc Relat Phenom 10:333-347

61. Chadwick D, Katrib A (1974) Photoelectron spectra of acetaldehyde and acetyl halides. J Electron Spectrosc Relat Phenom 3:39-52

62. Trott WM, Blais NC, Walters EA (1978) Molecular beam photoionization study of acetone and acetone-d6. J Chem Phys 69(7):3150-3158

63. Alkorta I, Blanco F, Solimannejad M, Elguero J (2008) Competition of hydrogen bonds and halogen bonds in complexes of hypohalous acids with nitrogenated bases. J Phys Chem A 12:10856-10863

64. Wang W, Zhang Y, Ji B (2010) On the difference of the properties between the blue-shifting halogen bond and the blue-shifting hydrogen bond. J Phys Chem A 114:7257-7260

65. Mohan N, Suresh CH (2014) A molecular electrostatic potential analysis of hydrogen, halogen, and dihydrogen bonds. J Phys Chem A 118:1697-1705

66. An X, Zhao H, Wang Y, Li Q (2013) Competition between hydrogen bonds and halogen bonds in complexes of formamidine and hypohalous acids. J Mol Mod 19:4529-4535

67. Wu W, Zeng Y, Li X, Zhang X, Zheng S, Meng L (2013) Interplay between halogen bonds and hydrogen bonds in $\mathrm{OH} /$ $\mathrm{SH} \cdots \mathrm{HOX} \cdots \mathrm{HY}(\mathrm{X}=\mathrm{Cl}, \mathrm{Br} ; \mathrm{Y}=\mathrm{F}, \mathrm{Cl}, \mathrm{Br})$ complexes. J Mol Mod 19:1069-1077 
68. Scheiner S, Grabowski SJ, Kar T (2001) Influence of hybridization and substitution on the properties of the $\mathrm{CH} \cdots \mathrm{O}$ hydrogen bond. J Phys Chem A 105:10607-10612

69. Li X, Schlegel B (2002) On the physical origin of blue-shifted hydrogen bonds. J Am Chem Soc 124:9639-9647

70. Sosa GL, Peruchena NM, Contreras RH, Castro E (2002) Topological and NBO analysis of hydrogen bonding interactions involving $\mathrm{C}-\mathrm{H}$... O bonds. J Mol Struct 577:219-228

71. Kryachko ES, Zeegers-Huyskens Th (2001) Theoretical Study of the $\mathrm{CH} \cdots \mathrm{O}$ interaction in fluoromethanes $\mathrm{H}_{2} \mathrm{O}$ and chloromethanes $\mathrm{H}_{2} \mathrm{O}$ complexes. J Phys Chem A 105:7118-7125

72. Alabugin IV, Manoharan M (2003) Electronic basis of improper hydrogen bonding: a subtle balance of hyperconjugation and rehybridization. J Am Chem Soc 125:5973-5987

73. Nguyen HMT, Peters J, Zeegers-Huyskens Th (2006) Theoretical study of the blue-shifting hydrogen bonds between $\mathrm{CH}_{2} \mathrm{X}_{2}$ and $\mathrm{CHX}_{3}(\mathrm{X}=\mathrm{F}, \mathrm{Cl}, \mathrm{Br})$ and hydrogen peroxide. $\mathrm{J}$ Mol Struct 792:16-22

74. Joseph J, Jemmis ED (2007) Red-, blue-, or no-shift in hydrogen bonds: a unified explanation. J Am Chem Soc 129:4620-4632

75. Li AY (2007) Chemical origin of blue- and redshifted hydrogen bonds: intramolecular hyperconjugation and its coupling with intermolecular hyperconjugation. J Chem Phys 126:154102-154112

76. Badger RM, Bauer SH (1937) Spectroscopic studies of the hydrogen bond. II. The shift of the O-H vibrational frequency in the formation of the hydrogen bond. J Chem Phys 5:839

77. Badger RM (1940) The relation between the energy of a hydrogen bond and the frequencies of the $\mathrm{O}-\mathrm{H}$ bands. J Chem Phys $8: 288$ 